\title{
Effects of rumen undegradable protein sources on nitrous oxide, methane and ammonia emission from the manure of feedlot-finished cattle
}

\section{Larissa de Melo Coelho ( $\sim$ larissacoelhomc@gmail.com )}

Universidade Estadual Paulista - Faculdade de Ciências Agrárias e Veterinárias

\section{Liziane de Figueiredo Brito}

Universidade Estadual Paulista - Faculdade de Ciências Agrárias e Veterinárias

Juliana Duarte Messana

Universidade Estadual Paulista - Faculdade de Ciências Agrárias e Veterinárias

Abmael da Silva Cardoso

Universidade Estadual Paulista - Faculdade de Ciências Agrárias e Veterinárias

Geovany Macêdo Carvalho

Universidade Estadual Paulista - Faculdade de Ciências Agrárias e Veterinárias

Rodrigo de Nazaré Santos Torres

Universidade Estadual Paulista - Faculdade de Ciências Agrárias e Veterinárias

Roberta Souto Carlos

Universidade Estadual Paulista - Faculdade de Ciências Agrárias e Veterinárias

Euclides Braga Malheiros

Universidade Estadual Paulista - Faculdade de Ciências Agrárias e Veterinárias

Mara Cristina Pessôa Cruz

Universidade Estadual Paulista - Faculdade de Ciências Agrárias e Veterinárias

Telma Teresinha Berchielli

Universidade Estadual Paulista - Faculdade de Ciências Agrárias e Veterinárias

\section{Research Article}

Keywords: animal feeding, climate change, greenhouse gases, livestock, nitrogen

Posted Date: September 2nd, 2021

DOI: https://doi.org/10.21203/rs.3.rs-857348/v1

License: (c) (i) This work is licensed under a Creative Commons Attribution 4.0 International License.

Read Full License 


\section{Abstract}

Here, the effects of sources of rumen undegradable protein (RUP) in diets on methane $\left(\mathrm{CH}_{4}\right)$, nitrous oxide $\left(\mathrm{N}_{2} \mathrm{O}\right)$ and ammonia $\left(\mathrm{NH}_{3}\right)$ emissions from the manure of feedlot-finished cattle were evaluated. We hypothesized that the use of different RUP sources in diets would reduce $\mathrm{N}$ loss via urine and contribute to reduced $\mathrm{N}_{2} \mathrm{O}, \mathrm{CH}_{4}$ and $\mathrm{NH}_{3}$ emissions to the environment. Nellore cattle received different diets (18 animals/treatment), including soybean meal (SM, RDP source), by-pass soybean meal (BSM, RUP source) and corn gluten meal (CGM, RUP source). The protein source did not affect the $\mathrm{N}$ and $\mathrm{C}$ concentration in urine, $\mathrm{C}$ concentration in feces, and $\mathrm{N}$ balance $(P>0.05)$. The RUP sources resulted in a higher $\mathrm{N}_{2} \mathrm{O}$ emission than the RDP source $(P=0.030)$, while $B S M$ resulted in a higher $\mathrm{N}_{2} \mathrm{O}$ emission than $\operatorname{CGM}(P=0.038)\left(S M=633, B S M=2521\right.$, and $\left.C G M=1153 \mathrm{~g} \mathrm{ha}^{-2} \mathrm{~N}-\mathrm{N}_{2} \mathrm{O}\right)$; however, there were no differences in $\mathrm{CH}_{4}$ and $\mathrm{NH}_{3}$ emission $(\mathrm{P}>0.05)$. In conclusion, the use of RUP in diets did not affect $\mathrm{N}$ excretion of beef cattle or $\mathrm{CH}_{4}$ and $\mathrm{NH}_{3}$ emission from manure, but increased $\mathrm{N}_{2} \mathrm{O}$ emission from the manure.

\section{Introduction}

The finishing phase in feedlots enables the use of food sources that are adequate for the animal's requirements, yielding in higher productivity and meat quality [1]. However, this system is responsible for a greater accumulation of manure, which contains several components such as $\mathrm{N}$ and organic materials [2]. These components may undergo transformation and serve as a source of emission of greenhouse gases (GHGs), such as nitrous oxide $\left(\mathrm{N}_{2} \mathrm{O}\right)$ and methane $\left(\mathrm{CH}_{4}\right)[3 ; 4 ; 5)$, as well as of ammonia $\left(\mathrm{NH}_{3}\right)$ $[6 ; 7)$. Greenhouse gas emissions contribute to global warming [8], whereas $\mathrm{NH} 3$ volatilization harms human health $[9 ; 7]$ and potentially increase $\mathrm{GHG}$ emissions as $\mathrm{NH} 3$ is a precursor for $\mathrm{N}_{2} \mathrm{O}$ generation [10].

$\mathrm{N}_{2} \mathrm{O}$ is emitted through the transformation of ammonium $\left(\mathrm{NH}_{4}^{+}\right)$and nitrate $\left(\mathrm{NO}_{3}{ }^{-}\right)$in soil during nitrification, denitrification [11], and nitrifier denitrification [12] mediated by fungi, bacteria and archaea [13]. These processes are affected by precipitation, temperature and substrate availability $(14 ; 15)$. The magnitude of gas emission from cattle manure depends on the form and concentration of $\mathrm{N}$ [16]. Therefore, the reduction of $\mathrm{N}$ loss via ruminant excreta, specifically of $\mathrm{N}$ in the form of urea, is relevant to mitigate $\mathrm{N}_{2} \mathrm{O}$ emission, since $70 \%$ of the $\mathrm{N}$ excreted by ruminants is in the form of urea, which releases $\mathrm{NH}_{4}{ }^{+}$following hydrolysis [17]. In addition, microbial hydrolysis of urea results in $\mathrm{NH}_{3}$ emission [18]; thus, the reduction of loss of $\mathrm{N}$-urea from excreta might directly reduce $\mathrm{NH}_{3}$ emission [19].

The amount of $\mathrm{CH}_{4}$ emitted from manure is small compared with the total amount of enteric $\mathrm{CH}_{4}$ produced by ruminants [20]. However, emission from manure in feedlots is relevant, because high amounts of manure can result in higher $\mathrm{CH}_{4}$ emission [21]. $\mathrm{N}$ and $\mathrm{C}$ content [22], moisture, and 
temperature [23], are the major modulators of $\mathrm{CH}_{4}$ emissions. Thus, reducing nutrient excretion by animals may serve as a strategy to mitigate $\mathrm{CH}_{4}$ emission from manure.

Optimizing the use of $\mathrm{N}$ by ruminants can reduce $\mathrm{N}$ loss through urine and, therefore, minimize $\mathrm{NH}_{3}$, [7] and $\mathrm{N}_{2} \mathrm{O}$ emission from manure (24). Reducing the amount of rumen degradable protein (RDP) and increasing the amount of ruminal undegradable protein (RUP) in diets may increase rumen $\mathrm{N}$ use efficiency and enable adequate supply of metabolizable protein (PM) to the small intestine [25]. Thus, we hypothesized that different sources of RUP in the diets would reduce $\mathrm{N}$ loss via urine and contribute to decreased $\mathrm{N}_{2} \mathrm{O}, \mathrm{CH}_{4}$, and $\mathrm{NH}_{3}$ emissions to the environment. Therefore, the objective of the present study was to evaluate the effects of sources of RUP in diets on $\mathrm{N}_{2} \mathrm{O}, \mathrm{CH}_{4}$ and $\mathrm{NH}_{3}$ emissions from manure of feedlot-finished Nellore and identify key driving variables that regulate the production of these gases.

\section{Results}

\section{Characterization of animals' excreta and $\mathrm{N}$ balance}


Table 1

Fecal and urinary $\mathrm{N}$ content and $\mathrm{C}$ and $\mathrm{N}$ balance of Nellore cattle fed with sources of rumen undegradable protein during the finishing phase in feedlots.

\begin{tabular}{|c|c|c|c|c|c|c|}
\hline \multirow[t]{2}{*}{ Variables } & \multicolumn{3}{|c|}{ Treatments $^{1}$} & \multirow[t]{2}{*}{ SEM $^{2}$} & \multicolumn{2}{|l|}{$p$ value } \\
\hline & SM & BSM & CGM & & SM vs. RUP & BSM vs. CGM \\
\hline \multicolumn{7}{|c|}{ Chemical composition } \\
\hline \multicolumn{7}{|l|}{ Feces } \\
\hline $\mathrm{N}, \mathrm{g} \mathrm{kg}^{-1} \mathrm{DM}$ & 33.6 & 33.2 & 34.9 & 0.5 & 0.444 & 0.012 \\
\hline C, $\mathrm{g} \mathrm{kg}^{-1} \mathrm{DM}$ & 409.7 & 413.0 & 410.4 & 3.9 & 0.695 & 0.637 \\
\hline $\mathrm{C} / \mathrm{N}$ & 12.2 & 12.4 & 11.7 & 0.18 & 0.658 & 0.009 \\
\hline \multicolumn{7}{|l|}{ Urine } \\
\hline $\mathrm{N}, \mathrm{g} \mathrm{kg}^{-1} \mathrm{DM}$ & 5.1 & 6.1 & 5.6 & 0.8 & 0.419 & 0.669 \\
\hline C, $\mathrm{g} \mathrm{kg}^{-1} \mathrm{DM}$ & 8.2 & 10.8 & 8.8 & 1.5 & 0.382 & 0.186 \\
\hline $\mathrm{C} / \mathrm{N}$ & 1.5 & 1.8 & 1.4 & 0.1 & 0.632 & $<0.001$ \\
\hline \multicolumn{7}{|l|}{$\mathrm{N}$ balance } \\
\hline \multicolumn{7}{|l|}{$\mathrm{N}, \mathrm{g} \mathrm{day}^{-1}$} \\
\hline Intake & 223.1 & 209.8 & 204.6 & 10.4 & 0.224 & 0.724 \\
\hline Fecal excretion & 86.4 & 89.6 & 82.4 & 5.5 & 0.952 & 0.358 \\
\hline Urinary excretion & 83.4 & 75.8 & 77.8 & 5.8 & 0.391 & 0.659 \\
\hline Total excretion & 169.8 & 165.4 & 160.2 & 9.3 & 0.548 & 0.691 \\
\hline Total retention & 53.3 & 44.3 & 44.4 & 5.4 & 0.194 & 0.995 \\
\hline \multicolumn{7}{|l|}{$\mathrm{N}, \%$ intake } \\
\hline Fecal N & 38.7 & 42.7 & 39.8 & 1.2 & 0.101 & 0.097 \\
\hline Urinary N & 37.6 & 36.0 & 38.5 & 2.3 & 0.913 & 0.450 \\
\hline $\mathrm{N}$ retention & 23.7 & 21.2 & 21.7 & 2.2 & 0.428 & 0.886 \\
\hline
\end{tabular}

${ }^{1} \mathrm{SM}=$ manure of animals fed soybean meal as a source of rumen degradable protein (RDP), BSM = manure of animals fed by-pass soybean meal as a source of rumen undegradable protein (RUP), CGM = manure of animals fed corn gluten meal as a source of RUP; ${ }^{2} \mathrm{SEM}=$ standard error of the mean. Animal considered as an experimental unit $(n=9)$. 


\begin{tabular}{|c|c|c|c|c|c|c|}
\hline \multirow[t]{2}{*}{ Variables } & \multicolumn{3}{|c|}{ Treatments ${ }^{1}$} & \multirow[t]{2}{*}{ SEM $^{2}$} & \multicolumn{2}{|l|}{$p$ value } \\
\hline & SM & BSM & CGM & & SM vs. RUP & BSM vs. CGM \\
\hline Urine & 51.3 & 54.5 & 51.2 & 1.9 & 0.521 & 0.227 \\
\hline Feces & 48.7 & 45.5 & 48.8 & 1.9 & 0.521 & 0.227 \\
\hline
\end{tabular}

There were no differences in the $\mathrm{C}$ and $\mathrm{N}$ content or $\mathrm{C} / \mathrm{N}$ of the urine and fecal samples between the RUP and RDP sources $(P>0.05)$ (Table 1 ). Inclusion of CGM as a source of RUP in the diet increased $N$ content $(P=0.012)$ but decreased the $C / N$ in the fecal samples compared with the inclusion of $B S M$ as a source of RUP $(P=0.009)$. However, there were no differences in the $C / N$ of urine samples between the RUP and RDP sources $(P=0.632)$.

None of the three evaluated protein sources affected $\mathrm{N}$ consumption, fecal and urinary $\mathrm{N}$ excretion, total $\mathrm{N}$ excretion and total $\mathrm{N}$ retention $(\mathrm{P}>0.05)$. There were no differences in fecal and urinary $\mathrm{N}$ excretion, $\mathrm{N}$ retention (\% intake) or fecal and urinary $\mathrm{N}$ excretion (\% excreted) among the three protein sources $(\mathrm{P}>$ 0.05).

\section{Gases emission}

Mean temperature during the $\mathrm{N}_{2} \mathrm{O}$ and $\mathrm{CH}_{4}$ emission sampling period was $20^{\circ} \mathrm{C}$; the lowest $\left(3.3^{\circ} \mathrm{C}\right)$ and highest $\left(35.2^{\circ} \mathrm{C}\right)$ temperatures were recorded close to sampling day 49 and on the last sampling day, respectively. Cumulative precipitation throughout the experimental period was $33.6 \mathrm{~mm}$, occurring over 7 different days (Fig. 1).

Daily mean $\mathrm{N}_{2} \mathrm{O}$ and $\mathrm{CH}_{4}$ fluxes varied from -62 to $318 \mu \mathrm{g} \mathrm{N} \mathrm{O}_{2} \mathrm{~m}^{2} \mathrm{~h}^{-1}$ and from -125 to $321 \mu \mathrm{CH}_{4} \mathrm{~m}^{2}$ $h^{-1}$, respectively, during the experimental period (Fig. 2). Higher peak of $\mathrm{N}_{2} \mathrm{O}$ emission was observed in the 21st day, in all treatments. At this same day, an increase in $\mathrm{CH}_{4}$ fluxes was also observed. Differences in $\mathrm{N}_{2} \mathrm{O}$ and $\mathrm{CH}_{4}$ fluxes among treatments occurred in some days of evaluation and were not consistent along the studied period.

Protein sources did not affect cumulative $\mathrm{CH}_{4}$ emission from animal manure $(P>0.05)$ (Table 2). However, the manure of animals fed RUP sources resulted in a higher cumulative $\mathrm{N}_{2} \mathrm{O}$ emission than that of animals fed the RDP source ( $P=0.030)$, and emissions almost doubled in CGM and quadrupled in BSM. Moreover, the manure of animals receiving BSM resulted in a higher cumulative $\mathrm{N}_{2} \mathrm{O}$ emission than that of animals receiving CGM $(P=0.038)$. 
Table 2

Cumulative $\mathrm{CH}_{4}$ and $\mathrm{N}_{2} \mathrm{O}$ emissions from the manure of Nellore cattle fed with sources of rumen undegradable protein during the finishing phase in feedlots.

\begin{tabular}{|c|c|c|c|c|c|c|}
\hline \multirow[t]{2}{*}{ Variables, $\mathrm{g} \mathrm{ha}^{-1}$} & \multicolumn{3}{|c|}{ Treatments $^{1}$} & \multirow[t]{2}{*}{ SEM $^{2}$} & \multicolumn{2}{|l|}{$p$ value } \\
\hline & SM & BSM & CGM & & SM vs. RUP & BSM vs. CGM \\
\hline $\mathrm{CH}_{4}-\mathrm{C}$ & 1352 & 801 & 834 & 429 & 0.320 & 0.957 \\
\hline $\mathrm{N}_{2} \mathrm{O}-\mathrm{N}$ & 633 & 2521 & 1153 & 430 & 0.030 & 0.038 \\
\hline \multicolumn{7}{|c|}{$\begin{array}{l}{ }^{1} \mathrm{SM}=\text { manure of animals fed soybean meal as a source of rumen degradable protein (RDP), BSM = } \\
\text { manure of animals fed by-pass soybean meal as a source of rumen undegradable protein (RUP), } \\
\text { CGM = manure of animals fed corn gluten meal as a source of RUP; }{ }^{2} S E M=\text { standard error of the } \\
\text { mean. Chamber considered as an experimental unit }(n=9) \text {. The cumulative values refer to } 112 \text { days } \\
\text { of feedlot. }\end{array}$} \\
\hline
\end{tabular}

An interaction between sampling time and protein source was observed for $\mathrm{DM}, \mathrm{OM}, \mathrm{N}, \mathrm{C}$ and $\mathrm{NH}_{4}{ }^{+}(\mathrm{Table}$ 3 , Fig. 3). The manure of animals fed CGM presented a lower $\mathrm{N}$ content and higher $\mathrm{NH}_{4}{ }^{+}$than that of animals fed SM on day $42(\mathrm{P}<0.001)$, while on day 63 higher values of $\mathrm{N}$ and $\mathrm{NH}_{4}{ }^{+}$were observed for the manure of animals fed CGM in relation to $B S M(P=0.002$ and $P=0.010$ respectively $)$ and $S M(P=0.004$ and $P<0.001$, respectively). The manure of animals fed $S M$ showed a higher $C$ content than that of animals fed RUP on day $42(P=0.001)$. The manure of animals fed $S M$ showed a higher $\mathrm{C} / \mathrm{N}$ than that of animals fed RUP $(P=0.001) . \mathrm{NO}_{3}{ }^{-}$content of the analyzed samples was not detectable.

There were no correlations of manure gases $\left(\mathrm{N}_{2} \mathrm{O}\right.$ and $\left.\mathrm{CH}_{4}\right)$ emissions with $\mathrm{N}, \mathrm{C}, \mathrm{C} / \mathrm{N}$ ratio, DM, OM, and $\mathrm{NH}_{4}{ }^{+}(\mathrm{P}>0.05)$ (Table 4). $\mathrm{N}$ was positively correlated with $\mathrm{C}(\mathrm{P}<0.001)$ and $\mathrm{OM}(\mathrm{P}<0.002)$. $\mathrm{C}$ was positively correlated with $\mathrm{C} / \mathrm{N}$ ratio $(P<0.001) . \mathrm{NH}_{4}{ }^{+}$was positively correlated with $\mathrm{OM}(\mathrm{P}=0.045)$

A positive correlation was observed between $\mathrm{CH}_{4}$ and $\mathrm{C} / \mathrm{N}$ ratio on day $42(\mathrm{P}=0.025)$, and between $\mathrm{CH}_{4}$ and $\mathrm{NH}_{4}{ }^{+}$on day $63(\mathrm{P}=0.001)$. On day $105, \mathrm{~N}_{2} \mathrm{O}$ was positively correlated with $\mathrm{DM}(\mathrm{P}=0.018)$ and $\mathrm{NH}_{4}{ }^{+}$ $(P=0.008)($ Table 5). 
Table 3

Chemical composition of the manure, deposited in the soil, of Nellore cattle fed with sources of rumen undegradable protein during the finishing phase in feedlot.

\begin{tabular}{|c|c|c|c|c|c|c|c|c|}
\hline \multirow[t]{2}{*}{$\operatorname{Var}^{1}$} & \multicolumn{3}{|c|}{ Treatment $^{2}$} & \multirow[t]{2}{*}{ SEM } & \multicolumn{4}{|l|}{$p$ value } \\
\hline & SM & BSM & CGM & & SM vs. RUP & BSM vs. CGM & $\mathrm{T}^{4}$ & TR vs. $T^{5}$ \\
\hline DM & 710 & 642 & 608 & 42 & 0.204 & 0.260 & 0.239 & 0.030 \\
\hline $\mathrm{OM}$ & 629 & 678 & 677 & 15 & 0.231 & 0.036 & 0.057 & 0.044 \\
\hline $\mathrm{N}$ & 28.4 & 27.5 & 29.2 & 0.4 & 0.039 & 0.167 & 0.050 & $<0.001$ \\
\hline C & 341 & 324 & 332 & 6 & 0.913 & 0.077 & 0.201 & $<0.001$ \\
\hline $\mathrm{C} / \mathrm{N}$ & 12.1 & 11.8 & 11.5 & 0.1 & 0.001 & 0.061 & 0.002 & 0.297 \\
\hline $\mathrm{NH}_{4}^{+}$ & 304 & 400 & 532 & 39 & 0.001 & 0.1026 & 0.001 & $<0.001$ \\
\hline $\mathrm{NO}_{3}{ }^{-}$ & - & - & - & - & - & - & - & - \\
\hline \multicolumn{9}{|c|}{$\begin{array}{l}{ }^{1} \mathrm{DM}=\text { dry matter }\left(\mathrm{g} \mathrm{kg}^{-1}\right), \mathrm{OM}=\text { organic matter }\left(\mathrm{g} \mathrm{kg}^{-1}\right), \mathrm{N}=\text { nitrogen }\left(\mathrm{g} \mathrm{kg}^{-1}\right), \mathrm{C}=\text { carbon }\left(\mathrm{g} \mathrm{kg}^{-1}\right), \\
\mathrm{NH}_{4}^{+} \text {ammonium }\left(\mathrm{mg} \mathrm{kg}^{-1}\right) ;{ }^{2} \mathrm{SM}=\text { manure of animals fed soybean meal as a source of rumen } \\
\text { degradable protein }(\mathrm{RDP}), \mathrm{BSM}=\text { manure of animals fed by-pass soybean meal as a source of rumen } \\
\text { undegradable protein (RUP), CGM = manure of animals fed corn gluten meal as a source of } \\
\mathrm{RUP} \cdot{ }^{3} \mathrm{SEM}=\text { standard error of the mean; }{ }^{4} \mathrm{~T}=\text { time; }{ }^{5} \text { Interaction TR (treatments = SM, BSM and CGM) } \times \\
\mathrm{T}(\text { time). Chamber considered as an experimental unit }(\mathrm{n}=9) \text {. }\end{array}$} \\
\hline
\end{tabular}

Table 4

Pearson's correlation coefficients between explanatory variables during the evaluated period.

\begin{tabular}{|c|c|c|c|c|c|c|c|}
\hline Variables $^{1}$ & $\mathrm{CH}_{4}-\mathrm{C}$ & $\mathbf{N}$ & C & $\mathrm{C} / \mathrm{N}$ & DM & OM & $\mathrm{NH}_{4}^{+}$ \\
\hline $\mathrm{N}_{2} \mathrm{O}-\mathrm{N}$ & 0.018 & -0.104 & -0.103 & -0.015 & -0.014 & -0.012 & -0.035 \\
\hline $\mathrm{CH}_{4}-\mathrm{C}$ & & -0.016 & 0.092 & 0.210 & -0.074 & -0.081 & -0.058 \\
\hline$N$ & & & $0.851^{*}$ & -0.137 & 0.207 & $0.329 *$ & 0.062 \\
\hline C & & & & $0.401^{\star}$ & 0.126 & 0.355 & 0.018 \\
\hline $\mathrm{C} / \mathrm{N}$ & & & & & -0.133 & 0.092 & -0.070 \\
\hline DM & & & & & & -0.183 & 0.115 \\
\hline OM & & & & & & & 0.224 * \\
\hline \multicolumn{8}{|c|}{$\begin{array}{l}\text { * Represents a statistical significance }(\mathrm{P} \leq 0.05) \text { for the coefficients of correlation. Analyses were } \\
\text { carried out using data from all evaluated days. }{ }^{1} \mathrm{DM}=\text { dry matter, } \mathrm{OM}=\text { organic matter, } \mathrm{NH}_{4}^{+}= \\
\text {ammonium }\end{array}$} \\
\hline
\end{tabular}


Table 5

Pearson's correlation coefficients between explanatory variables on each sampling day.

\begin{tabular}{|c|c|c|c|c|c|c|}
\hline Variables $^{1}$ & $\mathbf{N}$ & $C$ & $\mathrm{C} / \mathrm{N}$ & DM & OM & $\mathrm{NH}_{4}^{+}$ \\
\hline & \multicolumn{6}{|c|}{ Day 42} \\
\hline $\mathrm{N}_{2} \mathrm{O}-\mathrm{N}$ & 0.047 & 0.022 & -0.022 & 0.001 & 0.192 & -0.122 \\
\hline \multirow[t]{2}{*}{$\mathrm{CH}_{4}-\mathrm{C}$} & 0.051 & 0.297 & 0.430 * & 0.003 & -0.152 & 0.014 \\
\hline & \multicolumn{6}{|c|}{ Day 63} \\
\hline $\mathrm{N}_{2} \mathrm{O}-\mathrm{N}$ & -0.197 & -0.182 & 0.050 & 0.018 & 0.254 & 0.030 \\
\hline \multirow[t]{2}{*}{$\mathrm{CH}_{4}-\mathrm{C}$} & -0.037 & 0.081 & 0.252 & -0.268 & 0.174 & $0.592^{\star}$ \\
\hline & \multicolumn{6}{|c|}{ Day 105} \\
\hline $\mathrm{N}_{2} \mathrm{O}-\mathrm{N}$ & 0.069 & 0.093 & -0.004 & $0.449 *$ & 0.120 & $0.497 *$ \\
\hline $\mathrm{CH}_{4}-\mathrm{C}$ & 0.155 & 0.202 & -0.017 & 0.252 & 0.201 & 0.159 \\
\hline
\end{tabular}

\section{$\mathrm{NH}_{3}$ emission}

Mean temperature during the $\mathrm{NH}_{3}$ emission sampling period was $25^{\circ} \mathrm{C}$. The lowest $\left(15.2^{\circ} \mathrm{C}\right)$ and highest $\left(37.3^{\circ} \mathrm{C}\right)$ temperatures were recorded on the first sampling day and on day 19 , respectively. Cumulative precipitation throughout the experimental period was $320.5 \mathrm{~mm}$, occurring over 30 days (Fig. 4).

Manure from all treatments showed the highest daily mean $\mathrm{NH}_{3}$ emission on the first day of evaluation (Fig. 5a). Subsequently, $\mathrm{NH}_{3}$ emission decreased until the fourth day of evaluation under all treatments. From the 19th day, a new peak of $\mathrm{NH}_{3}$ emission was observed under all treatments, with the BSM treatment reaching the highest emission on the 31st day. The SM treatment presented a small increase in $\mathrm{NH}_{3}$ emission on days 38 and 51, while the BSM and CGM treatments presented a decrease in emission. $\mathrm{NH}_{3}$ emission under all treatments completely ceased on the 77th day. From day 13 to 25 , cumulative $\mathrm{NH}_{3}$ emission under the SM treatment was higher than that under the BSM and CGM treatments (Fig. 5b). However, after this period, no differences were observed among the treatments. 
Table 6

Cumulative $\mathrm{NH}_{3}$ emission and manure characteristics of Nellore cattle fed with sources of rumen undegradable protein during the finishing phase in feedlot.

\begin{tabular}{|c|c|c|c|c|c|c|}
\hline \multirow[t]{2}{*}{ Variables $^{1}$} & \multicolumn{3}{|c|}{ Treatment $^{2}$} & \multirow[t]{2}{*}{ SEM $^{3}$} & \multicolumn{2}{|l|}{$p$ value } \\
\hline & SM & BSM & CGM & & SM vs. RUP & BSM vs. CGM \\
\hline $\mathrm{NH}_{3}, \mathrm{~kg} \mathrm{ha}^{-1}$ & 800 & 784 & 882 & 117 & 0.528 & 0.505 \\
\hline $\mathrm{DM}, \mathrm{g} \mathrm{kg}^{-1} \mathrm{DM}$ & 913. & 800 & 827 & 59 & 0.231 & 0.312 \\
\hline $\mathrm{OM}, \mathrm{g} \mathrm{kg}^{-1} \mathrm{DM}$ & 565 & 618 & 579 & 24 & 0.475 & 0.197 \\
\hline $\mathrm{N}, \mathrm{g} \mathrm{kg}^{-1} \mathrm{DM}$ & 24.4 & 24.9 & 24.7 & 0.4 & 0.432 & 0.77 \\
\hline C, $\mathrm{g} \mathrm{kg}^{-1} \mathrm{DM}$ & 271 & 309 & 287 & 14 & 0.185 & 0.163 \\
\hline $\mathrm{C} / \mathrm{N}$ & 11.1 & 11.3 & 10.7 & 0.1 & 0.487 & $<0.001$ \\
\hline $\mathrm{NH}_{4}{ }^{+}, \mathrm{mg} \mathrm{kg}^{-1} \mathrm{DM}$ & 276 & 188 & 180 & 13 & $<0.001$ & 0.697 \\
\hline \multicolumn{7}{|c|}{$\begin{array}{l}{ }^{1} \mathrm{NH}_{3}=\text { accumulated values during } 77 \text { days of evaluation. } \mathrm{DM}=\text { dry matter, } \mathrm{OM}=\text { organic matter; }{ }^{2} \mathrm{SM} \\
=\text { manure of animals fed soybean meal as a source of rumen degradable protein (RDP), BSM }= \\
\text { manure of animals fed by-pass soybean meal as a source of rumen undegradable protein (RUP), }\end{array}$} \\
\hline
\end{tabular}

There were no significant differences in cumulative $\mathrm{NH}_{3}$ emission from the manure during the evaluated period and manure content of $\mathrm{DM}, \mathrm{OM}, \mathrm{N}$, and $\mathrm{C}(\mathrm{P}>0.05)$ among the three protein sources (Table 6). Likewise, there were no differences in the $\mathrm{C} / \mathrm{N}$ ratio of the manure between the RDP and RUP sources $(P=$ 0.491). However, the manure of animals fed BSM showed a higher $\mathrm{C} / \mathrm{N}$ ratio than that of animals fed CGM $(P<0.001)$. The manure of animals fed RDP showed a higher $\mathrm{NH}_{4}{ }^{+}$concentration than that of animals fed RUP $(\mathrm{P}<0.001)$; however, there were no differences in $\mathrm{NH}_{4}{ }^{+}$concentration between the manure of animals fed CGM and BSM $(P=0.670)$.

\section{Discussion}

\section{Gases emission}

The use of RUP sources in the diet did not reduce $\mathrm{N}$ loss via urine. Meanwhile, it increased $\mathrm{N}_{2} \mathrm{O}$ emission but did not affect $\mathrm{CH}_{4}$ emission from manure. Therefore, our hypothesis that RUP inclusion in the diet would reduce $\mathrm{N}$ loss and contribute to reduced $\mathrm{N}_{2} \mathrm{O}$ and $\mathrm{CH}_{4}$ emissions from the manure was rejected.

The manure deposited in the soil enhances its $\mathrm{N}$ and $\mathrm{C}$ content, thereby altering the $\mathrm{N}$ mineralization rate and stimulating $\mathrm{N}_{2} \mathrm{O}$ production $(26 ; 27)$. Meanwhile, labile $\mathrm{C}$ released during material decomposition 
regulates the seasonality of $\mathrm{N}_{2} \mathrm{O}$ and $\mathrm{N}_{2}$ production [28]. Inorganic forms of $\mathrm{N}\left(\mathrm{NH}_{4}{ }^{+}\right.$and $\left.\mathrm{NO}_{3}{ }^{-}\right)$are determinants of $\mathrm{N}_{2} \mathrm{O}$ production. The manure of animals fed BSM and CGM presented a higher $\mathrm{NH}_{4}{ }^{+}$ concentration than that of animals fed SM in the 42nd day, and in 63rd only for the CGM treatment, evidencing a temporal variation of the manure characteristics in relation to treatments, probably resulting in higher urea hydrolysis at these moments (Table 3, Fig. 3). The higher $\mathrm{NH}_{4}{ }^{+}$concentration under the RUP treatments may have promoted nitrification or denitrification, resulting in $\mathrm{N}_{2} \mathrm{O}$ production [29] (Table 2).

A reduction in urinary $\mathrm{N}$ was expected with the inclusion of RUP in diets, since an increase in $\mathrm{N}$ use efficiency is observed when lower RDP amounts are used in the diet [30]; in other words, reduced $\mathrm{NH}_{3}$ concentration in the rumen was compensated via increased urea recycling to maintain an optimum ruminal $\mathrm{NH}_{3}$ concentration for maximum microbial growth, thus decreasing its $\mathrm{N}$ urinary excretion. [25; $30 ; 31$. However, this did not occur because the content of RDP in diets with RUP likely met the microbial demand for $\mathrm{N}$, thereby not achieving sufficient urea recycling and allowing urinary $\mathrm{N}$ excretion similar to the diet with RDP (Table 1).

Elevated amount of amino acids reaching the small intestine is another factor contributing to a greater $\mathrm{N}$ loss. When absorbed in excess or in imbalance relative to the animal's requirements, these amino acids can be oxidized for energy production, leading to urea production in the liver, which is then excreted via urine. This might occur when the diet offers adequate levels of $\mathrm{NH}_{3}$ to meet the ruminal demand [33]. Therefore, excess CP concentration in the diet, either as RDP or RUP, may contribute to urinary $\mathrm{N}$ excretion.

The greatest $\mathrm{N}_{2} \mathrm{O}$ emission from the manure of animals fed the RUP sources (Table 3 ) indicates that these diets probably resulted in a higher urea content of the manure, since $\mathrm{N}_{2} \mathrm{O}$ emission is particularly affected by the urinary amount of urea [34].

A higher $\mathrm{C} / \mathrm{N}$ ratio promotes a greater $\mathrm{N}_{2} \mathrm{O}$ emission, as $\mathrm{N}$ is abundant for microbial growth and proliferation, which results in liquid $\mathrm{N}$ mineralization and promotes nitrification and denitrification [35]. The $\mathrm{C} / \mathrm{N}$ ratio of the feces and urine (Table 1), were higher in the BSM treatment than in the CGM treatment, in manure, the RUP source was higher than RDP (Table 3), however, the differences observed for $\mathrm{C} / \mathrm{N}$ do not seem to be sufficient to result in differences in $\mathrm{N}_{2} \mathrm{O}$ emission.

When higher RDP levels are used in the diet, a change in the route of urine-to-feces excretion is expected due to a higher amount of intact protein that reaches the intestine, which contributes to fecal $\mathrm{N}$ excretion when not absorbed [36; 37). However, there were no differences in fecal $\mathrm{N}$ excretion between the RDP and RUP treatments (Table 1), although fecal $\mathrm{N}$ concentration differed between the two RUP sources. This might be attributed to the distinct amino acid composition or the different chemical structures of these sources. The processes through which corn (corn gluten, a by-product of wet corn milling) and soybean 
(thermally treated) have been subjected can make the protein undegradable in the rumen or unavailable [38].

Despite different compositions of the manure among the treatments (Table 3), there were no differences in $\mathrm{CH}_{4}$ emission (Table 2). $\mathrm{N}$ and $\mathrm{OM}$ contents and $\mathrm{C} / \mathrm{N}$ ratio of manure are important factors associated with $\mathrm{CH}_{4}$ emission [39; 40]. Nevertheless, differences in manure chemical composition among the treatments were observed in some sampling days (Fig. 3). This result can be related to variations in environmental conditions, such as temperature and precipitation, which can alter the chemical composition of manure. However, these differences among the treatments were not consistent throughout the experimental period, justifying the lack of differences in $\mathrm{CH}_{4}$ emission.

In manure, most of the $\mathrm{N}$ content comes from $\mathrm{N}$ excreted via urine in the form of urea, which is rapidly hydrolyzed to $\mathrm{NH}_{4}{ }^{+}$, and and $\mathrm{N}$ losses from organic forms of feces also occurs [41]. Organic $\mathrm{N}$ can promote $\mathrm{CH}_{4}$ emission, playing an important role in the transformation of acetate to $\mathrm{CH}_{4}$ [42], whereas mineral $\mathrm{N}$ as $\mathrm{NH}_{4}{ }^{+}$can inhibit $\mathrm{CH}_{4}$ production, breaking the link between acidification and methanogenesis in anaerobic processes [43].

$\mathrm{N}_{2} \mathrm{O}$ and $\mathrm{CH}_{4}$ fluxes varied from -62 to $318 \mu \mathrm{g} \mathrm{N} \mathrm{O}_{2} \mathrm{~m}^{2} \mathrm{~h}^{-1}$ and from -125 to $321 \mu \mathrm{g} \mathrm{CH}_{4} \mathrm{~m}^{2} \mathrm{~h}^{-1}$, respectively, during the experimental period (Fig. 2). These fluxes showed a great variation, which can be attributed to several factors, such as the temporal variation in the chemical composition of manure due to variations in climatic conditions, as explained above (Table 3, Fig. 3). [44] have reported a large variation in emissions, mainly associated with irregular fecal and urine deposition on the surface, which may also have occurred in the present study.

Frequent deposition and accumulation of feces and urine in the soil did not increase $\mathrm{CH}_{4}$ and $\mathrm{N}_{2} \mathrm{O}$ emissions over time under all treatments. Trampling by animals may not have provided a favorable environment for the action of methanogenic bacteria and nitrifying/denitrifying microorganisms. In addition, the humidity in the feedlot did not increase over time, based on the DM content of the manure, except on rainy days (Table 3). This is probably related to the dry climate at that time of year, associated with the compacted soil of the feedlot.

Precipitation and temperature changes strongly affect $\mathrm{CH}_{4}$ emission [45]. During the study period, $\mathrm{CH}_{4}$ flux was related to these variables. On the 21 th day, increased emission peaks were observed under all treatments, probably due to precipitation in the previous week. Considering that $\mathrm{CH}_{4}$ emission occurs under anaerobic conditions, precipitation may have favored higher emissions due to increased moisture content of the manure [46]. On the 49th day, reduced $\mathrm{CH}_{4}$ emission was observed, possibly due to temperature drop on that day. Considering that $\mathrm{CH}_{4}$ emission is a biological and anaerobic process, temperature can act as a limiting by reducing methanogen activity [47]. After this period, $\mathrm{CH}_{4}$ emission tended to stabilize, probably due to the absence of high precipitation and and little variation in temperature (Fig. 1). 
The mean $\mathrm{CH}_{4}$ emission under all treatments during the finishing phase in the feedlot $\left(\mathrm{SM}=53 \mu \mathrm{CH}_{4}\right.$ $\mathrm{m}^{2} \mathrm{~h}^{-1} ; \mathrm{BSM}=33 \mu \mathrm{g} \mathrm{CH}_{4} \mathrm{~m}^{2} \mathrm{~h}^{-1} ; \mathrm{CGM}=16 \mu \mathrm{g} \mathrm{CH}_{4} \mathrm{~m}^{2} \mathrm{~h}^{-1}$ ) in the present study was lower than that reported by [48] under similar climatic conditions and a pen density of $6 \mathrm{~m}^{2}$ per animal as well as those reported by [49] under distinct climatic conditions and a pen density of $40 \mathrm{~m}^{2}$ per animal. The low moisture of the manure was possibly responsible for low $\mathrm{CH}_{4}$ emissions, because even under favorable chemical conditions, microbial activity is limited at low moisture levels. Of note, the density in each pen was $30 \mathrm{~m}^{2}$ per animal and the evaluations were performed near the feeders, in an area of $6.5 \mathrm{~m} \times 10 \mathrm{~m}$ with higher excreta deposition. The density of animals is reflected in the condition of excreta deposition and accumulation on the surface, and it a relevant factor to be considered when evaluating gas emissions in feedlots [49].

On some sampling days, $\mathrm{CH}_{4}$ uptake occurred predominantly through the consumption of atmospheric $\mathrm{CH}_{4}$, which can occur in aerobic environments [39]. The environment is a $\mathrm{CH}_{4}$ source when the balance between methanogenic production and methanotrophic consumption is positive, leading to $\mathrm{CH}_{4}$ emission. In contrast, when this balance is negative, the environment is considered a $\mathrm{CH}_{4}$ sink [39].

Considering that the feedlot system has emerged as a management strategy to minimize the impacts of lower forage production in the dry season, majority of feedlots in Brazil are managed from April to November, when rainfall is scarce and temperature is low. The climatic conditions during this period, when associated with feedlots of low animal density, can result in low $\mathrm{CH}_{4}$ emission. The present results demonstrate that the use of feedlots in the dry season in tropical environments can reduce $\mathrm{CH}_{4}$ emission, and this system can be considered an efficient mitigation strategy for GHG emission.

The mean $\mathrm{N}_{2} \mathrm{O}$ fluxes ( $\mathrm{SM}=22 \mu \mathrm{g} \mathrm{N} \mathrm{N}_{2} \mathrm{~m}^{2} \mathrm{~h}^{-1} ; \mathrm{BSM}=59 \mu \mathrm{g} \mathrm{N} \mathrm{O}_{2} \mathrm{~m}^{2} \mathrm{~h}^{-1} ; \mathrm{CGM}=36 \mu \mathrm{g} \mathrm{N}_{2} \mathrm{O} \mathrm{m}^{2} \mathrm{~h}^{-1}$ ) observed in the present study were similar to the values reported by [49] but lower than the values reported by [44] and [50]. A higher peak of $\mathrm{N}_{2} \mathrm{O}$ emission was observed on the 21st day under all treatments, possibly due to rainfall in the previous week. Similarly, [50] have reported increased emissions following precipitation events.

Post-rainfall emissions and wetting of the area might be related to a combination of mineralization, nitrification, and/or denitrification, leading to the release of $\mathrm{N}_{2} \mathrm{O}$ absorbed in the dry soil [51]. Moisture is an important factor in $\mathrm{N}_{2} \mathrm{O}$ production, particularly when associated with an optimum temperature and a propitious chemical composition [52; 53). However, after reaching the peak, $\mathrm{N}_{2} \mathrm{O}$ emissions remained stable, with small variations across evaluation days; even in the presence of additional precipitation events, low temperature may have hampered the occurrence of new emission peaks.

$\mathrm{NO}_{3}{ }^{-}$was not detectable in the manure during the experiment. $\mathrm{N}_{2} \mathrm{O}$ production is assumed to occur through nitrification, via the oxidation of $\mathrm{NH}_{4}{ }^{+}$in hydroxylamine $\left(\mathrm{NH}_{2} \mathrm{OH}\right)$, with $\mathrm{NOH}$ as an intermediate and $\mathrm{N}_{2} \mathrm{O}$ as the product [54]. $\mathrm{N}_{2} \mathrm{O}$ can also be produced through denitrification by nitrifiers, wherein $\mathrm{NH}_{3}$ is 
nitrified and oxidized to nitrite $\left(\mathrm{NO}_{2}{ }^{-}\right)$, which is then reduced to nitric oxide (NO), $\mathrm{N}_{2} \mathrm{O}$, and molecular $\mathrm{N}$ $\left(\mathrm{N}_{2}\right) ; \mathrm{N}_{2} \mathrm{O}$ is an intermediate in the reduction of $\mathrm{NO}_{2}{ }^{-}$to $\mathrm{N}_{2}$ [55]. During denitrification, $\mathrm{NO}_{3}{ }^{-}$is used as the primary substrate [56]. Denitrification may not have occurred in the present study.

Correlation analyses showed no significant linear associations of $\mathrm{CH}_{4}$ and $\mathrm{N}_{2} \mathrm{O}$ production with the tested variables related to the chemical composition of manure, which can be attributed to specific factors (Tables 4 and 5). The processes underlying the production of gases are complex and rely on the chemical composition of manure. Meanwhile, manure composition is dependent on other factors such as temperature, moisture, deposition conditions, and trampling by animals. The absence of significant correlations between gas production and manure composition may be related to the small variation in the characteristics analyzed during the sampling period, making it difficult to observe relationships among variables.

$\mathrm{NH}_{3}$ emission

The use of RUP in the diet did not reduce $\mathrm{N}$ loss via urine and did not influence $\mathrm{NH}_{3}$ emission from the manure. In this sense, our hypothesis that RUP inclusion in the diet would reduce $\mathrm{N}$ loss and contribute to decreased $\mathrm{NH}_{3}$ emission was rejected.

The manure of animals fed SM presented higher $\mathrm{NH}_{3}$ emissions than that of animals fed CGM and BSM from the 8th to 25th day of evaluation. This may be attributed to the higher $\mathrm{NH}_{4}{ }^{+}$content of the manure of animals fed SM than that of animals fed CGM and BSM at the beginning of the sampling period (Table 6). Subsequently, the manure of animals fed CGM and BSM presented a new $\mathrm{NH}_{3}$ emission peak following the event of the highest precipitation $(54.2 \mathrm{~mm})$ throughout the experimental period. However, during this period, most of the $\mathrm{NH}_{4}{ }^{+}$from the $\mathrm{SM}$ treatment had already been used, as reflected by the weak response to precipitation under this treatment. Urea present in the urine and feces is rapidly hydrolyzed, and the formed $\mathrm{NH}_{4}{ }^{+}$is dissociated to aqueous $\mathrm{NH}_{3}$, depending on $\mathrm{NH}_{4}{ }^{+}$concentration and $\mathrm{pH}$ of manure and environmental conditions. When precipitation occurs, urease activity is promoted, resulting in increased $\mathrm{NH}_{3}$ emission [57]. Of note, however, manure sampling for characterization was performed before implanting the chambers in the area. Thus, the chemical composition data presented herein do not represent the possible temporal variations during the $\mathrm{NH}_{3}$ evaluation period (Table 3).

Higher values of $\mathrm{NH}_{3}$ emission have been reported ( $49.1 \mathrm{~kg} \mathrm{NH}_{3}$ animal $\left.{ }^{-1}\right)$ in beef cattle feedlots, which is mainly related to the fact that majority of the confinements are performed outdoors, given that wind speed in open environments increases emission [58]. According to [19], daily $\mathrm{NH}_{3}$ emission in feedlots rarely exceeds $2,000 \mu \mathrm{g} \mathrm{NH}_{3} \mathrm{~m}^{-3}$; however, in the present study, higher values were observed. Importantly, as explained before, the evaluations were performed in an area of higher excreta deposition, with the objective of comparing the treatments in homogeneous conditions of excreta distribution; therefore, the amount of emission by area may have been overestimated in this study. Furthermore, the fact of using an acid soaked sponge to collect $\mathrm{NH}_{3}$ possibly removed more $\mathrm{NH}_{3}$ from the soil/manure surface compared 
to the non-invasive micro-meteorological measurement method. Conversely, we did not account for emissions when the animals were present in the feedlots. Throughout the sampling period, the animals had already been removed from the area, and there was a large amount of accumulated manure. When the wet season starts, emission may have been favoured by increased moisture content due to the large amount of available substrate [19]. Therefore, part of the urea excreted by the animals was hydrolyzed only when the moisture content increased as a function precipitation.

Over time, as no new manure was deposited due to the absence of animals in the area, emission probably ceased when the substrate was consumed, which occurred around the 77th day in the present study. In experiments in which excreta from the animals is collected and then applied to the soil for evaluation in the absence of animals and new depositions, ammonia emission occurs for 3 weeks on average (40; 59; 60). Therefore, further studies are warranted to investigate $\mathrm{NH}_{3}$ emission in open feedlots and to observe peaks occurrence in the presence of animals, maintaining the evaluations also after removing the animals, in the next rainy season.

\section{Conclusions}

The inclusion of RUP in the diet did not affect $\mathrm{N}$ excretion by animals. While the $\mathrm{N}_{2} \mathrm{O}$ emission from the manure was increased, $\mathrm{CH}_{4}$ emission and $\mathrm{NH}_{3}$ emission remained unaffected. Additional studies are warranted to investigate the effects of using different proportions of RDP and RUP in diets on $\mathrm{NH}_{3}, \mathrm{~N}_{2} \mathrm{O}$, and $\mathrm{CH}_{4}$ emissions from the manure of animals managed in feedlot systems under tropical conditions.

\section{Material And Methods}

The experimental was approved by the Ethics, Bioethics, and Animal Welfare Committee of São Paulo State University (UNESP), Jaboticabal, under protocol numbered 16.668/16. All methods were carried out in accordance with relevant guidelines and regulations. Methods are reported in the manuscript following the recommendations in the ARRIVE guidelines.

\section{Site description}

The present study was conducted at the Campus of Jaboticabal of the São Paulo State University, Sao Paulo, Brazil ( $21^{\circ} 14^{\prime} 05^{\prime \prime} S, 48^{\circ} 17^{\prime} 09^{\prime \prime W}$; altitude, $\left.615.01 \mathrm{~m}\right)$. The region has a tropical climate, with a dry season from April to September and a wet season from October to March, during which over $80 \%$ of the annual precipitation occurs. The soil is Rhodic Ferralsol [61] derived from basalt, with a sandy-clayloam texture $\left(10 \%\right.$ silt and $61 \%$ sand) in the surface layer $(0-10 \mathrm{~cm})$. The soil $\mathrm{pH}$ in $\mathrm{CaCl}_{2}$ is 5.9 , bulk density is $1.8 \mathrm{~kg} \mathrm{dm}^{-3}$, and organic matter content is $16.6 \mathrm{~g} \mathrm{dm}^{-3}$ at the same depth.

Meteorological data (daily precipitation and ambient temperature) were obtained from the dataset of the Agrometeorological Station of the Department of Exact Sciences, Universidade Estadual Paulista (UNESP), Campus of Jaboticabal, located $1 \mathrm{~km}$ from the experimental area. 


\section{Experimental design}

The experiment was conducted from May to December 2019, lasting precisely 210 days. The first 21 days were dedicated to animal adaptation to the diet, followed by 112 days of confinement, during which weekly sampling of $\mathrm{N}_{2} \mathrm{O}$ and $\mathrm{CH}_{4}$ was performed. After removing the animals from the feedlots, $\mathrm{NH}_{3}$ was sampled for 77 days.

Fifty-four Nellore bulls with an initial body weight of approximately $360 \mathrm{~kg}$ were distributed in three treatments. The animals were divided into three treatments and allocated in collective pens $(11 \mathrm{~m} \times 50 \mathrm{~m}$; one pen per treatment and 18 animals per pen), with dirt floor and collective drinkers for every two pens and two covered automated feeders in each pen (INTERGADO®, Intergado Ltd., Contagem, Minas Gerais, Brazil) system equipped with an automated feeder monitor resting on load cells, allowing electronic registration of the amount of feed consumed by animal. The trough recognizes the animal from the electronic ear, automatically sends consumption data to a database, and stores the information

The experimental design was completely randomized, with nine replicates per treatment $(n=9$; each chamber of gas evaluation was an experimental unit), arranged in an area of $65 \mathrm{~m}^{2}$, near the feeders, where the manure (feces and urine) was deposited the most frequently.

Manure of animals fed with sources of protein (two sources of RUP and one source of RDP as a control) was collected, resulting in three treatments as follows:

1) Soybean meal (SM): source of RDP.

2) By-pass soybean meal (BSM): source of RUP

3) Corn gluten meal (CGM): source of RUP.

The experimental diets were composed of $30 \%$ roughage and $70 \%$ concentrate, formulated to meet the average daily gain (GMD) of $1.5 \mathrm{~kg} \mathrm{day}^{-1}$, according to BR CORTE [62]. The diets were offered at 08.00 and $16.00 \mathrm{~h}$. The amounts offered were sufficient to allow a daily leftover of $5 \%-10 \%$ of the total offered.

The ingredients of the diets were analyz ed for chemical composition (Table 7). The AOAC [63] method was used to determine dry matter (DM) (method 930.15), crude protein (CP) (method 990.03), organic matter (OM) (method 942.05), and ether extract (EE) (method 920.39) content. Neutral detergent fiber (NDF) content was determined according to the method described by [64] using ANKOM® 2000 (Ankom Technologies, New York, USA) with thermostable a-amylase and without sodium sulfite, corrected for ashes and residual proteins. The RDP and RUP content was estimated based on the protein fraction [65] and degradation rate of each fraction, considering a passage rate of $5 \% \mathrm{~h}^{-1}$. 
Table 7

Ingredients and chemical composition of the diets.

\begin{tabular}{|c|c|c|c|}
\hline \multirow[t]{2}{*}{ Diet composition, $\mathrm{g} \mathrm{kg}^{-1} \mathrm{DM}$} & \multicolumn{3}{|l|}{ Diets $^{1}$} \\
\hline & SM & BSM & CGM \\
\hline Corn silage & 300.2 & 299.7 & 301.5 \\
\hline Ground corn & 134.6 & 134.4 & 134.2 \\
\hline Citric pulp & 383.0 & 397.5 & 421.6 \\
\hline Soybean meal & 172.7 & - & - \\
\hline By-pass soybean meal & - & 159.0 & - \\
\hline Corn gluten meal & - & - & 132.3 \\
\hline Mineral mix & 9.4 & 9.4 & 10.4 \\
\hline \multicolumn{4}{|l|}{ Chemical composition $^{2}$} \\
\hline Dry matter, $\mathrm{g} \mathrm{kg}^{-1}$ as fed & 538.1 & 538.4 & 537.2 \\
\hline Organic matter, $\mathrm{g} \mathrm{kg}^{-1} \mathrm{DM}$ & 918.9 & 917.9 & 925.1 \\
\hline Total digestible nutrients, $\mathrm{g} \mathrm{kg}^{-1} \mathrm{DM}$ & 745.7 & 741.3 & 751.3 \\
\hline Crude protein, $\mathrm{g} \mathrm{kg}^{-1} \mathrm{DM}$ & 163.4 & 153.6 & 164.4 \\
\hline RDP, $\mathrm{g} \mathrm{kg}^{-1} \mathrm{CP}$ & 665.0 & 494.1 & 446.3 \\
\hline RUP, $\mathrm{g} \mathrm{kg}^{-1} \mathrm{CP}$ & 335.0 & 505.9 & 553.6 \\
\hline Neutral detergent fiber, $\mathrm{g} \mathrm{kg}^{-1} \mathrm{DM}$ & 301.9 & 321.5 & 302.5 \\
\hline Ether extract, $\mathrm{g} \mathrm{kg}^{-1} \mathrm{DM}$ & 39.5 & 40.0 & 39.2 \\
\hline Non-fibrous carbohydrates, $\mathrm{g} \mathrm{kg}^{-1} \mathrm{DM}$ & 414.2 & 402.8 & 419.0 \\
\hline \multicolumn{4}{|c|}{$\begin{array}{l}{ }^{1} \mathrm{SM}=\text { manure of animals fed soybean meal as a source of rumen degradable protein (RDP), BSM } \\
\text { manure of animals fed by-pass soybean meal as a source of rumen undegradable protein (RUP), } \\
\mathrm{CGM}=\text { manure of animals fed corn gluten meal as a source of RUP; }{ }^{2} \mathrm{DM}=\text { dry matter, } \mathrm{CP}=\text { crude } \\
\text { protein. }\end{array}$} \\
\hline
\end{tabular}

Gases $\left(\mathrm{N}_{2} \mathrm{O}, \mathrm{CH}_{4}\right.$ and $\left.\mathrm{NH}_{3}\right)$ were sampled using chambers placed on manure (feces and urine) deposited on the soil by animals subjected to treatments. At the time of evaluation, the chambers were randomly placed in an area $(6.5 \mathrm{~m} \times 10 \mathrm{~m})$ delimited near the feeders inside each confinement pen; specifically, an area of higher excreta deposition was selected with the objective of treatment comparison, thus avoiding evaluation in places without homogenous excreta distribution. 


\section{Evaluation of $\mathrm{N}_{2} \mathrm{O}$ and $\mathrm{CH}_{4}$ emissions}

$\mathrm{N}_{2} \mathrm{O}$ and $\mathrm{CH}_{4}$ emissions were determined using static closed chambers, according to the recommendations of the manual for GHG evaluation [66]. Plastic chambers $(0.6 \mathrm{~m} \times 0.4 \mathrm{~m} \times 0.24 \mathrm{~m})$ coated with a thermal insulator were positioned above the manure only at the time of gas collection, allowing the animals to trample, defecate and urinate freely around in the area. Sampling was performed once a week throughout the feedlot period (112 days), totaling 16 sampling events. Sampling was carried out between 16:00 and 16:20 am. The chambers were closed for $20 \mathrm{~min}$, and air samples were collected at 0,10 , and 20 min using a $50 \mathrm{~mL}$ polypropylene syringe and then transferred to previously evacuated chromatography flasks $(20 \mathrm{~mL})$. The temperature inside and outside the chamber was measured using a digital thermometer (Incoterm $\left.{ }^{\circledR}\right)$ to correct gas fluxes.

Air samples were analyzed using gas chromatography (Shimadzu Greenhouse Gas Analyzer GC-2014; Kyoto, Japan) under the following conditions: (1) $\mathrm{N}_{2} \mathrm{O}$ : injector temperature, $250^{\circ} \mathrm{C}$; column temperature, $80^{\circ} \mathrm{C} ; \mathrm{N}_{2}$ carrier gas $\left(30 \mathrm{~mL} \mathrm{~min}{ }^{-1}\right)$; and electron capture detector temperature, $325^{\circ} \mathrm{C}$; and (2) $\mathrm{CH}_{4}: \mathrm{H}_{2}$ flame gas $\left(30 \mathrm{~mL} \mathrm{~min}^{-1}\right)$ and flame ingestion detector temperature, $280^{\circ} \mathrm{C}$.

$\mathrm{N}_{2} \mathrm{O}\left(\mu \mathrm{g} \mathrm{N}-\mathrm{N}_{2} \mathrm{O} \mathrm{m}^{-2} \mathrm{~h}^{-1}\right)$ and $\mathrm{CH}_{4}\left(\mu \mathrm{g} \mathrm{C}-\mathrm{CH}_{4} \mathrm{~m}^{-2} \mathrm{~h}^{-1}\right)$ fluxes were calculated considering a linear increase in gas concentration inside the chamber during the closed period and corrected for ambient temperature, ambient pressure, and chamber dimensions, as follows:

Gas flow $=\left(\right.$ gas $\left.\left.\times M \omega \times V \times 60 \times 10^{-6}\right) / A \times \mathrm{VM}_{\text {corr }} \times 10^{-9}\right)$

where gas is the increment in the gas concentration inside the chamber during the closed period (ppb $\left.\min ^{-1}\right) ; M \omega$ is the molar mass of $\mathrm{N}-\mathrm{N}_{2} \mathrm{O}\left(28 \mathrm{~g} \mathrm{~mol}^{-1}\right)$ or $\mathrm{C}-\mathrm{CH}_{4}\left(12 \mathrm{~g} \mathrm{~mol}^{-1}\right)$; $V$ is the chamber volume $\left(\mathrm{m}^{3}\right) ; 60$ is the conversion factor from hour to minutes; $10^{-6}$ represents is the conversion factor from $\mathrm{g}$ to $\mu \mathrm{g} ; A$ is the chamber area $\left(\mathrm{m}^{2}\right) ; V M_{\text {corr }}$ is the molecular volume corrected by the normal conditions of temperature and pressure at the time of sampling; and $10^{-9}$ is the conversion factor from $\mathrm{ppb}$ to $\mu \mathrm{L} \mathrm{m}^{-3}$.

Fluxes were multiplied by 24 to obtain daily emissions, and the daily values were integrated through linear interpolation to obtain cumulative emissions during the evaluated period. Negative fluxes were included in the calculations to avoid biased data [67].

\section{Evaluation of $\mathrm{NH}_{3}$ emission}

After removing the animals from feedlots, $\mathrm{NH}_{3}$ volatilization was evaluated until the $\mathrm{NH}_{3}$ emission ceased by sampling on days $1,2,3,4,6,8,13,19,25,31,38,44,51,59,68$ and 77 after positioning the chamber. The chambers were randomly placed above the manure (feces and urine) in the previously delimited areas. Quantification was performed according to the methodology of static chamber described by [68], using semi-open chambers made of plastic bottles containing a foam soaked in $10 \mathrm{~mL}$ of $1.0 \mathrm{~mol}$ 
$\mathrm{dm}^{-3} \mathrm{H}_{2} \mathrm{SO}_{4}$ solution + glycerin $2 \%(\mathrm{v} / \mathrm{v})$ to capture $\mathrm{N}$. The amount of $\mathrm{N}-\mathrm{NH}_{3}$ retained in the foam was determined by distillation, following the Kjeldhal method (method 973.49) [63].

\section{Manure analysis}

Manure samples composed of feces and urine deposited in the compacted soil, trampled by the animals, were collected on days 42,63 and 105 after $\mathrm{N}_{2} \mathrm{O}$ and $\mathrm{CH}_{4}$ evaluations, directly above the ground surface at the places where the chambers were positioned, in order to represent the manure from the exact location where the gases were collected. The samples were analyzed for DM (method 930.15) [63], OM (method 942.05) [63], total C, total N (dry combustion method, using Leco® CN-828, Leco Corporation,

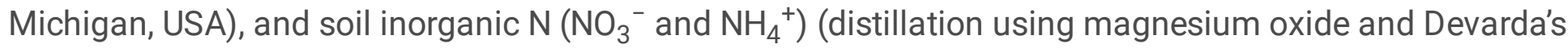
alloy, method 973.49) [63] content.

\section{Estimation of fecal and urinary production and $\mathrm{N}$ balance}

Fecal production was estimated using the internal marker technique [69] based on the indigestible NDF (NDFi) marker. Fecal sampling was performed from the 60th day after the animals entered the feedlots, for three consecutive days, immediately after stimulated defecation. Sampling was performed in the morning, middle of the day, and afternoon on the first, second, and third days, respectively. A composite fecal sample, by animal ( 9 animals/treatment), were made with the samples from these three days. The samples were mixed, homogenized, partially dried in a forced-air ventilation oven at $55^{\circ} \mathrm{C}$ for $72 \mathrm{~h}$, and milled in a mill with a $2 \mathrm{~mm}$ sieve. Samples of the ingredients of the animals' diets were collected, and their consumption was determined using the INTERGADO®

Fecal NDFi content was determined after incubating the samples in situ for $288 \mathrm{~h}$, using the method described by [70] followed by extraction with neutral detergent using an autoclave [71]. Fecal DM production was determined as the ratio of the concentration of the internal indicator ingested by the animal and its concentration in feces [72].

Urine samples were collected simultaneously with fecal samples. In brief, $50 \mathrm{~mL}$ aliquots of urine were sampled ("spot" sample) during stimulated urination for three consecutive days, as described by [73]. Creatinine concentration in the spot sample was determined with a colorimetric method using a commercial kit (Labtest $\left.{ }^{\circledR}\right)$. Urinary excretion was estimated based on the association between creatinine excretion and body weight using the equation proposed by [74]:

UCE $\left(\mathrm{g} \mathrm{day}^{-1}\right)=0.0345 \times \mathrm{BW}^{0.9491}$

Where UCE = urinary creatinine excretion and BW = body weight in $\mathrm{kg}$.

The fecal and urine samples were analyzed for total $\mathrm{C}$ and total $\mathrm{N}$ content using the dry combustion method with Leco® $\mathrm{CN}-828$ (Leco Corporation). The following equation was used to calculate nitrogen retention (NR): 
$\mathrm{NR}=\mathrm{NC}\left(\mathrm{g} \mathrm{day}^{-1}\right)-\left[\mathrm{EFN}\left(\mathrm{g} \mathrm{day}^{-1}\right)+\mathrm{EUN}\left(\mathrm{g} \mathrm{day}^{-1}\right)\right]$

where $\mathrm{NC}=\mathrm{N}$ consumption, $\mathrm{EFN}=$ excretion of fecal $\mathrm{N}$, and EUN $=$ excretion of urinary $\mathrm{N}$.

NR was expressed in grams per day and in percentage of NC, and fecal and urinary $\mathrm{N}$ excretion was expressed as the percentage of the total excreted.

\section{Statistics}

All statistical analyses were performed using SAS 9.4 (SAS Inc., Cary, NC). Response variables were analyzed in a completely randomized design using the PROC MIXED procedure Mean values were compared using orthogonal contrasts (SM vs. RUP and BSM vs. CGM) at a 5\% probability level.

Total $\mathrm{N}$, total $\mathrm{C}$, and $\mathrm{C} / \mathrm{N}$ in feces and urine and $\mathrm{N}$ balance were analyzed considering a model including the treatments (SM, BSM, and CGM) as fixed effects, animals (experimental unit in the RANDOM SAS option) and residual random error (NIID) of $\left(0, \sigma^{2}\right)$ as random effects.

Cumulative $\mathrm{N}_{2} \mathrm{O}, \mathrm{CH}_{4}$ and $\mathrm{NH}_{3}$ emissions, and manure characteristics (DM, OM, N, C, C/N, $\mathrm{NH}_{4}{ }^{+}$, and $\mathrm{NO}_{3}{ }^{-}$ of manure, sampled on day 0 , before the beginning of $\mathrm{NH}_{3}$ emissions measurements) were analyzed considering a model including the treatments (SM, BSM, and CGM) as fixed effects, chamber (experimental unit in the RANDOM SAS option) and residual random error (NIID) of $\left(0, \sigma^{2}\right)$ as random effects.

$\mathrm{N}_{2} \mathrm{O}$ and $\mathrm{CH}_{4}$ daily fluxes and manure characteristics $\left(\mathrm{DM}, \mathrm{OM}, \mathrm{N}, \mathrm{C}, \mathrm{C} / \mathrm{N}, \mathrm{NH}_{4}{ }^{+}\right.$, and $\mathrm{NO}_{3}{ }^{-}$, sampled on days 42,63 and 105 of $\mathrm{N}_{2} \mathrm{O}$ and $\mathrm{CH}_{4}$ evaluation) were analyzed using a repeated measures mixed model over time including the treatments (SM, BSM, and CGM), collection period and interaction as fixed effects, chamber (experimental unit and RANDOM SAS option) and residual random error (NIID) of $\left(0, \sigma^{2}\right)$ as random effects. Distinct covariance matrices were evaluated and the best structure was selected according to the Akaike information criterion (AIC).

Pearson correlation analysis between gases emission $\left(\mathrm{N}_{2} \mathrm{O}\right.$ and $\left.\mathrm{CH}_{4}\right)$ and chemical composition $(\mathrm{N}, \mathrm{C}$, $\mathrm{C} / \mathrm{N}, \mathrm{DM}, \mathrm{OM}$, and $\mathrm{NH}_{4}^{+}$) of the manure was performed separately for each sampling day (days 42,63 and 105 of manure evaluation), and also considering all data collected on these days.

\section{Declarations}

\section{CRediT authorship contribution statement}

L.M.C., J.D.M., A.S.C., L.F.B. and T.T.B. designed the experiment. L.M.C., G.M.C. and L.F.B. conducted the experiment and collected samples. L.M.C. and R.S.C. analysed the samples. L.MC., L.F.B., E.B.M., R.N.S.T. performed statistical analysis. L.M.C., L.F.B., J.D.M. and A.S.C. wrote the manuscript. L.M.C., J.D.M., 
A.S.C., L.F.B., M.C.P.C. and T.T.B. revised and edited the manuscript. All authors approved the final manuscript as shown.

\section{Declaration of competing interest}

The author(s) declare no competing interests.

\section{Acknowledgement}

This work was supported by the Fundação de Amparo à Pesquisa do Estado de São Paulo (2016/220224) and scholarship for L. M. Coelho (2019/11864-2) and A. S. Cardoso (2017/11274-5). The authors also want to acknowledge the Conselho Nacional de Desenvolvimento Científico e Tecnológico - CNPq for funding L. F. Brito (grant 118700/2017-0 and grant 103245/2020-0) and J. D. Messana (grant 103922/2019-9) and L. M. Coelho (grant 130981/2019-2). The authors also want to acknowledge the Coordenação de Aperfeiçoamento de Pessoal de Nível Superior (CAPES).

\section{References}

1 McAllister, T.A., et al. Nutrition, feeding and management of beef cattle in intensive and extensive production systems. In: Animal Agriculture. Academic Press. 75-98 (2020).

2 Griffin, T.S., He, Z., Honeycutt, C.W. Manure composition affects net transformation of nitrogen from dairy manures. Plant and Soil. 273, 29-38 (2005).

3 Møller, H.B., Moset, V., Brask, M., Weisbjerg, M.R. \& Lund, P. Feces composition and manure derived methane yield from dairy cows: Influence of diet with focus on fat supplement and roughage type. Atmos. Environ. 94, 36-43 (2014).

4 Zhu, G., et al. Characterizing $\mathrm{CH}_{4}$ and $\mathrm{N}_{2} \mathrm{O}$ emissions from an intensive dairy operation in summer and fall in China. Atmos. Environ. 83, 245-253 (2014).

5 Almeida, J.G.R. et al. Carbohydrate-rich supplements can improve nitrogen use efficiency and mitigate nitrogenous gas emissions from the excreta of dairy cows grazing temperate grass. Animal. 14, 11841195 (2020).

6 Lee, C., et al. Effects of metabolizable protein supply and amino acid supplementation on nitrogen utilization, milk production, and ammonia emissions from manure in dairy cows. J. Dairy Sci. 95, 52535268 (2012).

7 Groenestein, C.M., et al. Comparison of ammonia emissions related to nitrogen use efficiency of livestock production in Europe. J. Clean. Prod. 211, 1162-1170 (2019).

8 Meinshausen, M., et al. Greenhouse-gas emission targets for limiting global warming to $2^{\circ} \mathrm{C}$. Nature. 458, 1158-1162 (2009). 
9 Squizzato, S., et al. A procedure to assess local and long-range transport contributions to PM 2.5 and secondary inorganic aerosol. J. of Aerosol Sci. 46, 64-76 (2012).

10 IPCC - Intergovernmental Panel on Climate Change. 2019 Refinement to the IPCC Guidelines for National Greenhouse Gas Inventories. Chapter 10: Emissions from livestock and manure management, Geneva, Switzerland (2019).

11 Robertson, G.P. \& Groffman, P.M. Nitrogen transformations. n: Paul EA (ed) Soil Microbiology, Biochemistry and Ecology. Springer: New York, NY, USA, 341-364 (2007).

12 Wrage-Mönnig, N., Horn, M.A., Well, R., Müller, C., Velthof, G., Oenema, O. The role of nitrifier denitrification in the production of nitrous oxide revisited. Soil Biol. Biochem. 123, A3-A16 (2018).

$13 \mathrm{Xu}, \mathrm{X}$., et al. High temperatures inhibited the growth of soil bacteria and archaea but not that of fungi and altered nitrous oxide production mechanisms from different nitrogen sources in an acidic soil. Soil Biol. Biochem. 107, 168-179 (2017).

14 Van der Weerden, T.J., et al. G.J. Disaggregating nitrous oxide emission factors for ruminant urine and dung deposited onto pastoral soils. Agric. Ecosyst. Environ. 141, 426-436 (2011).

15 Sordi, A., et al. Nitrous oxide emission factors for urine and dung patches in a subtropical Brazilian pastureland. Agric. Ecosyst. Environ. 190, 94-103 (2014).

16 Cardoso, A. S., et al. $\mathrm{N}_{2} \mathrm{O}$ emissions from urine-treated tropical soil: Effects of soil moisture and compaction, urine composition, and dung addition. Catena. 157, 325-332. (2017).

17 Selbie, D.R., Buckthought, L.E. \& Shepherd, M.A. The challenge of the urine patch for managing nitrogen in grazed pasture systems. Adv. Agron. 129, 229-292 (2015).

18 Koenig, K.M., Mcginn, S.M. \& Beauchemin, K.A. Ammonia emissions and performance of backgrounding and finishing beef feedlot cattle fed barley-based diets varying in dietary crude protein concentration and rumen degradability. J. Anim. Sci. 91, 2278-2294 (2013).

19 Hristov, A.N., et al. Review: Ammonia emissions from dairy farms and beef feedlots. Can. J. Anim. Sci. 91, 1-35 (2011).

20 Benchaar, C. \& Hassanat, F. Methane emissions of stored manure from dairy cows fed conventional or brown midrib corn silage. J. Dairy Sci. 102, 10632-10638 (2019).

21 Jayasundara, S., Ranga Niroshan Appuhamy, J.A.D., Kebreab, E. \& Wagner-Riddle, C. Methane and nitrous oxide emissions from Canadian dairy farms and mitigation options: An updated review. Can. J. Anim. Sci. 96, 306-331 (2016). 
22 Choi, Y., Ryu, J. \& Lee, S. R. Influence of carbon type and carbon to nitrogen ratio on the biochemical methane potential, pH, and ammonia nitrogen in anaerobic digestion. J. Anim. Sci. and Technol. 62, 74 (2020).

23 Mazzetto, A.M., Barneze, A.S., Feigl, B.J., Van Groenigen, J.W., Oenema, O., Cerri, C.C. \& 2014. Temperature and moisture affect methane and nitrous oxide emission from bovine manure patches in tropical conditions. Soil Biol. Biochem. 76, 242-248.

24 Montes, R.F., et al. Mitigation of methane and nitrous oxide emissions from animal operations: II. A review of manure management mitigation options. SPECIAL TOPICS. J. Anim. Sci. 91, 5070-5094 (2013).

25 Calsamiglia, S., Ferret, A., Reynolds, C.K., Kristensen, N.B. \& Van Vuuren, A.M. Strategies for optimizing nitrogen use by ruminants. Animal. 4,1184 (2010).

26 Griffin, T.S., He, Z., Honeycutt, C.W. Manure composition affects net transformation of nitrogen from dairy manures. Plant and Soil. 273, 29-38 (2005).

27 Chen, S., et al. Organic carbon availability limiting microbial denitrification in the deep vadose zone. Environ. Microbiol. 20, 980-992 (2018).

28 Henry, S., et al. Disentangling the rhizosphere effect on nitrate reducers and denitrifiers: insight into the role of root exudates. Environ. Microbiol. 10, 3082-3092 (2008).

29 Selbie, D.R., Buckthought, L.E. \& Shepherd, M.A. The challenge of the urine patch for managing nitrogen in grazed pasture systems. Adv. Agron. 129, 229-292 (2015).

30 Silva, A.L., et al. Effects of rumen-undegradable protein on intake, performance, and mammary gland development in prepubertal and pubertal dairy heifers. J. Dairy Sci. 101, 5991-6001 (2018).

31 Detmann, E., Valente, E.E.L., Batista, E.D., Huhtanen, P. An evaluation of the performance and efficiency of nitrogen utilization in cattle fed tropical grass pastures with supplementation. Livest. Sci. 162, 141-153 (2014).

32 Schwab, C.G. \& Broderick, G.A.A. A 100-Year Review: Protein and amino acid nutrition in dairy cows. J. Dairy Sci. 100, 10094-10112 (2017).

33 Koenig, K.M. \& Beauchemin, K.A. Effect of feeding condensed tannins in high protein finishing diets containing corn distillers grains on ruminal fermentation, nutrient digestibility, and route of nitrogen excretion in beef cattle. J. Anim. Sci. v. 96, 4398-4413 (2018).

34 Zhou, K., Bao, Y. \& Zhao, G. Effects of dietary crude protein and tannic acid on nitrogen excretion, urinary nitrogenous composition and urine nitrous oxide emissions in beef cattle. J. Anim. Physiol. Anim. Nutr. 103, 1675-1683 (2019). 
35 Xia, F., Mei, K., Xu, Y., Zhang, C., Dahlgren, R.A., Zhang, M. Response of $\mathrm{N}_{2} \mathrm{O}$ emission to manure application in field trials of agricultural soils across the globe. Sci. Total Environ. 733, 139390 (2020).

36 Kebreab, E., France, J., Mills, J.A.N., Allison, R. \& Dijkstra, J. A dynamic model of N metabolism in the lactating dairy cow and an assessment of impact of $\mathrm{N}$ excretion on the environment. J. Anim. Sci. 80, 248-259 (2002).

37 Broderick, G.A. \& Reynal, S.M. Effect of source of rumen-degraded protein on production and ruminal metabolism in lactating dairy cows. J. Dairy Sci. 92, 2822-2834 (2009).

38 Stern, M.D., Bach, A. \& Calsamiglia, S. Alternative techniques for measuring nutrient digestion in ruminants. J. Anim. Sci. 75, 2256-2276 (1997).

39 Le Mer, J. \& Roger, P. Production, oxidation, emission and consumption of methane by soils: a review. Europ. J. Soil Boil. 37, 25-50 (2001).

40 Cardoso, A.S., et al.A.C. Seasonal effects on ammonia, nitrous oxide, and methane emissions for beef cattle excreta and urea fertilizer applied to a tropical pasture. Soil Tillage Res. 194, 104341 (2019).

41 Chadwick, D.R., et al. The contribution of cattle urine and dung to nitrous oxide emissions:

Quantification of country specific emission factors and implications for national inventories. Sci. Total Environ. 635, 607-617 (2018)

42 Cai, Z., Shan, Y., \& Xu, H. Effects of nitrogen fertilization on $\mathrm{CH}_{4}$ emissions from rice fields. J. Soil Sci. Plant Nutr. 53, 353-361 (2007).

43 Zhang, M., Lin, Q., Rui, J., Li, J., Li, X..Ammonium inhibition through the decoupling of acidification process and methanogenesis in anaerobic digester revealed by high throughput sequencing. Biotechnol. Lett. 39, 247-252 (2017).

44 Costa Junior, C., Li, C., Cerri, C.E. \& Cerri, C.C. Measuring and modeling nitrous oxide and methane emissions from beef cattle feedlot manure management: First assessments under Brazilian condition. $J$. Environ. Sci. Health, 49, 696-711 (2014).

$45 \mathrm{Li}, \mathrm{C}$., et al. Manure-DNDC: a biogeochemical process model for quantifying greenhouse gas and ammonia emissions from livestock manure systems. Nutr. Cycling Agroecosyst. 93, 163-200 (2012).

46 Gao, B., et al. Nitrous oxide and methane emissions from optimized and alternative cereal cropping systems on the North China Plain: a two-year field study. Sci. Total Environ. 472, 112-124 (2014).

47 Guo, G., et al. Effects of livestock manure properties and temperature on the methanogen community composition and methane production during storage. Environ. Technol. 41, 131-140 (2018). 
48 Costa Junior, C., Cerri, C.E., Pires, A.V. \& Cerri, C.C. Net greenhouse gas emissions from manure management using anaerobic digestion technology in a beef cattle feedlot in Brazil. Sci. Total Environ. 505, 1018-1025 (2015).

49 Liao, W., Liu, C. \& Gao, Z. Impacts of feedlot floor condition, deposition frequency, and inhibitors on $\mathrm{N}_{2} \mathrm{O}$ and $\mathrm{CH}_{4}$ emissions from feedlot dung and urine patches. J. Air Waste Manag. 68, 700-712 (2018).

50 Parker, D.B., et al. Temporal nitrous oxide emissions from beef cattle feedlot manure after a simulated rainfall event. J. Environ. Qual. 46, 733-740 (2017).

51 JØrgensen, R.N., JØrgensen, B.J. \& Nielsen, N.E. $\mathrm{N}_{2} \mathrm{O}$ emission immediately after rainfall in a dry stubble field. Soil Boil. Biochem. 30, 545-546 (1998).

52 Smith, K.A., et al. Exchange of greenhouse gases between soil and atmosphere: interactions of soil physical factors and biological processes. Eur. J. Soil Sci. 54, 779-791 (2003).

53 De Klein, C.A., Barton, L., Sherlock, R.R., Li, Z., Littlejohn, R.P. Estimating a nitrous oxide emission factor for animal urine from some New Zealand pastoral soils. Soil Research. 41, 381-399 (2003).

54 Li, S., et al. Microbial abundances predict methane and nitrous oxide fluxes from a windrow composting system. Front. Microbiol. 8, 409 (2017).

55 Wrage-Mönnig, N., Velthof, G.L., Van Beusichem, M.L., Oenema, O. Role of nitrifier denitrification in the production of nitrous oxide Soil Biol. Biochem. 33, 1723-1732 (2001).

56 Loick, N., et al. "Hot spots" of $\mathrm{N}$ and $\mathrm{C}$ impact nitric oxide, nitrous oxide and nitrogen gas emissions from a UK grassland soil. Geoderma. 305, 336-345 (2017).

57 Nichols, K.L., et al. Nitrous oxide and Ammonia emissions from cattle excreta on shortgrass steppe. J. Environ. Qual. 47, 419-426 (2018).

58 Wang, Y., et al. Mitigating greenhouse gas and ammonia emissions from beef cattle feedlot production: a system meta-analysis. Environ. Sci. Technol. 52, 11232-11242 (2018).

59 Lessa, A.C.R. et al. Bovine urine and dung deposited on Brazilian savannah pastures contribute differently to direct and indirect soil nitrous oxide emissions. Agric. Ecosyst. Environ. 190, $104-111$ (2014).

60 Bretas, I. L. et al. Nitrous oxide, methane, and ammonia emissions from cattle excreta on Brachiaria decumbens growing in monoculture or silvopasture with Acacia mangium and Eucalyptus grandis. Agric. Ecosyst. Environ. 295, 106896 (2020)

61 IUSS Working Group WRB. World Reference Base for Soil Resources 2014, Update 2015. International soil classification system for naming soils and creating legends for soil maps. World Soil Resources 
Reports No. 106. Rome: Food and Agriculture Organization (FAO) of the United Nations.

62 Valadares Filho, S.C., et al. (Eds.) Exigências Nutricionais de Zebuínos Puros e Cruzados. BR-CORTE. Viçosa, p.163-220 (2016).

63 AOAC. Official methods of analysis (15th ed). Association of Official Analytical Chemists, Washington, D.C (1990).

64 Mertens, D.R. Gravimetric determination of amylase-treated neutral detergent fiber in feeds with refluxing in beakers or crucibles: collaborative study. J. AOAC Internat. 85, 1217-1240 (2002).

65 Licitra, G., Hernandez, T.M. \& Van Soest, P.J. Standardization of procedures for nitrogen fractionation of ruminant feeds. Anim. Feed Sci. Technol. 57, 347-358 (1996).

66 Klein, C. \& Harvey, M. Nitrous oxide chamber methodology guidelines. 146 Global Research Alliance On Agricultural Greenhouse Gases, Wellington, New Zealand (2015).

67 Van Der Weerden, T.J., et al. Nitrous oxide emissions from urea fertilizer and effluent with and without inhibitors applied to pasture. Agric. Ecosyst. Environ. 219, 58-70 (2016).

68 Araújo, E.S. et al. Calibração de câmara semiaberta estática para quantificação de amônia volatilizada do solo. Pesquisa Agropecuária Brasileira. 44, 769-776 (2009).

69 Cochran, R.C., Adams, D.C., Wallace, J.D., Galyean, M.L., 1986. Predicting digestibility of different diets with internal markers: evaluation of four potential markers. J. Anim. Sci. 63, (1986).

70 Valente, T.N.P., et al. In situ estimation of indigestible compounds contents in cattle feed and feces using bags made from different textiles. Rev. Bras. Zootec. 40, 666-675 (2011).

71 Senger, C.C., et al. Evaluation of autoclave procedures for fibre analysis in forage and concentrate feedstuffs. Anim. Feed Sci. Technol. 146, 169-174 (2008).

72 Lopes, F.C.F., 2007. Determinação do consumo de forrageiras tropicais por vacas em lactação em condição de pastejo. Cadernos Técnicos de Veterinária e Zootecnia. 52, 1-116.

73 Chizzotti, M.L. et al. Consumo, digestibilidade e excreção de ureia e derivados de purinas em novilhas de diferentes pesos. Rev. Bras. Zootec. 35, 1813-1821 (2006).

74 Costa e Silva, L.F. et al. Creatinine excretion and relationship with body weight of Nellore cattle. Rev. Bras. Zootec. 41, 807-810, (2012).

\section{Figures}




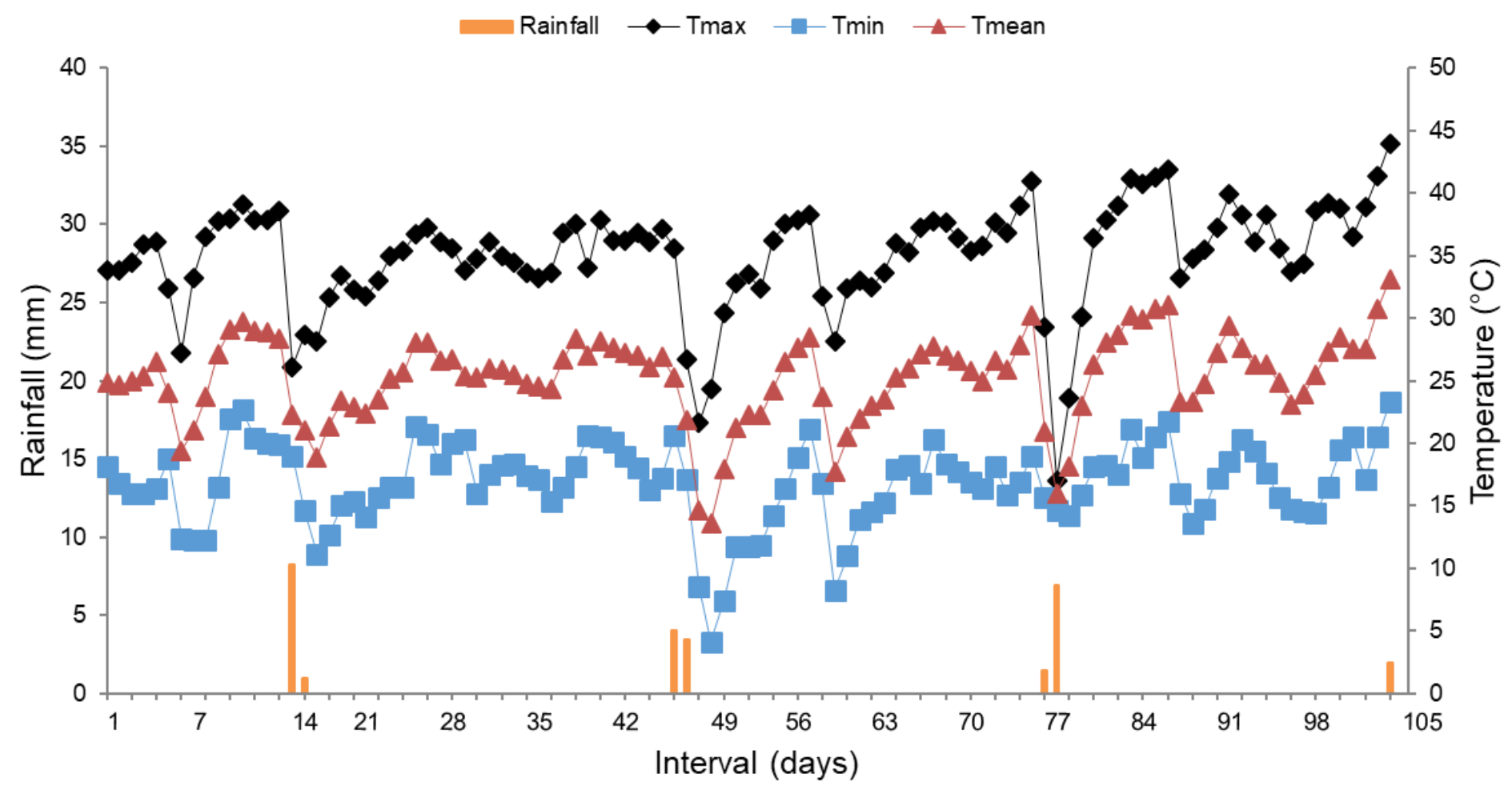

Figure 1

Daily rainfall and ambient temperature (daily minimum, mean and maximum) throughout the $\mathrm{N} 2 \mathrm{O}$ and $\mathrm{CH} 4$ emission sampling period. Data were retrieved from the Agrometeorological Station, Department of Exact Sciences (FCAV/UNESP), located at $1 \mathrm{~km}$ from the experimental area. 

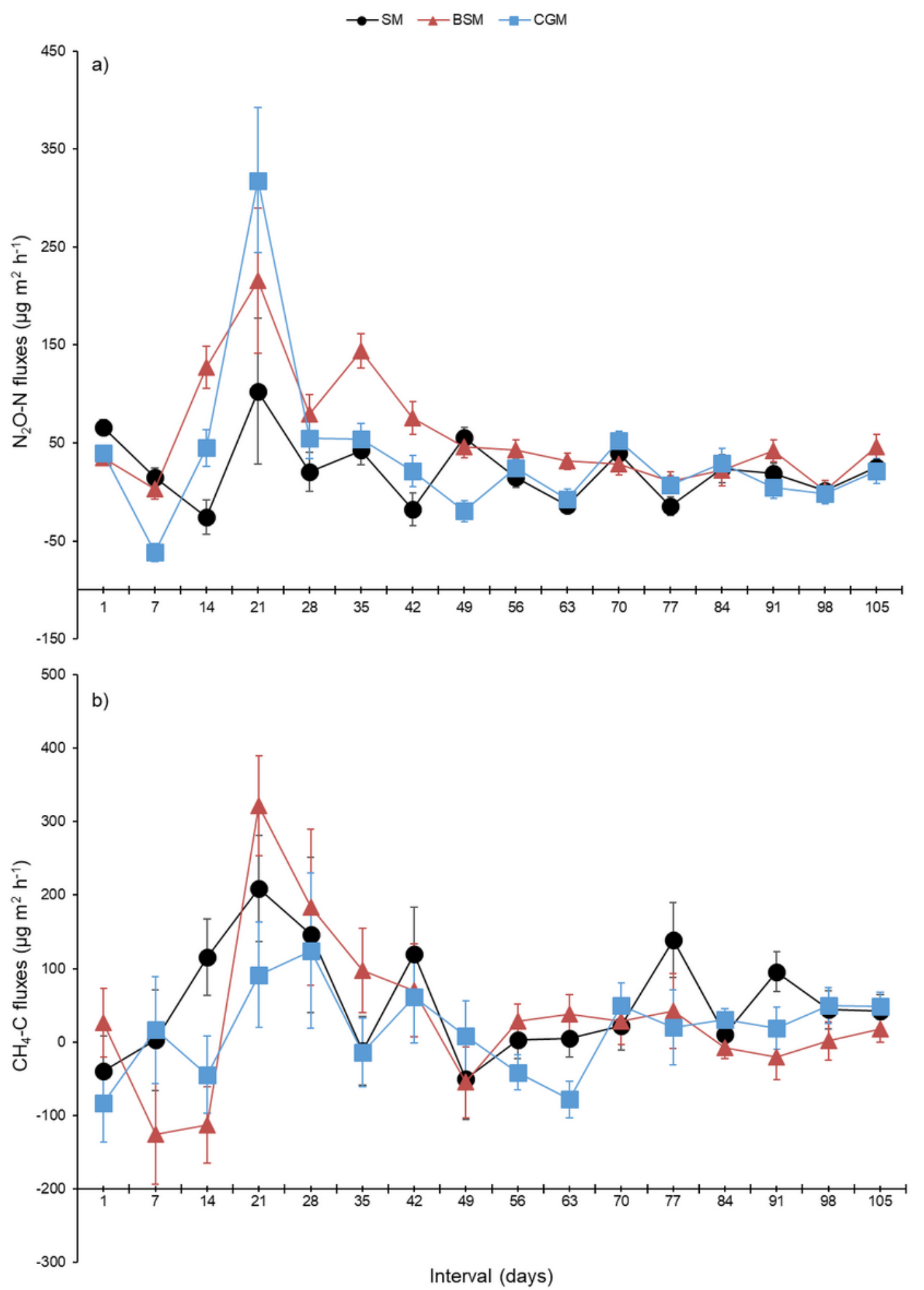

Figure 2

$\mathrm{N} 2 \mathrm{O}$ and $\mathrm{CH} 4$ fluxes from the manure of Nellore cattle fed with sources of rumen undegradable protein during the finishing phase in feedlots. $\mathrm{SM}=$ manure of animals fed soybean meal as a source of rumen degradable protein (RDP), BSM = manure of animals fed by-pass soybean meal as a source of rumen undegradable protein (RUP), $C G M=$ manure of animals fed gluten meal as a source of RUP. P-values for $\mathrm{N} 2 \mathrm{O}$ (treatment $=0.003$; time $<0.001$; treatment $\times$ time interaction $<0.001)$ and $\mathrm{CH} 4$ (treatment $=0.165$; 
time $<0.001$; treatment $\times$ time interaction $<0.005)$. Chamber considered as an experimental unit $(n=9)$. The error bars representing standard error of the mean.
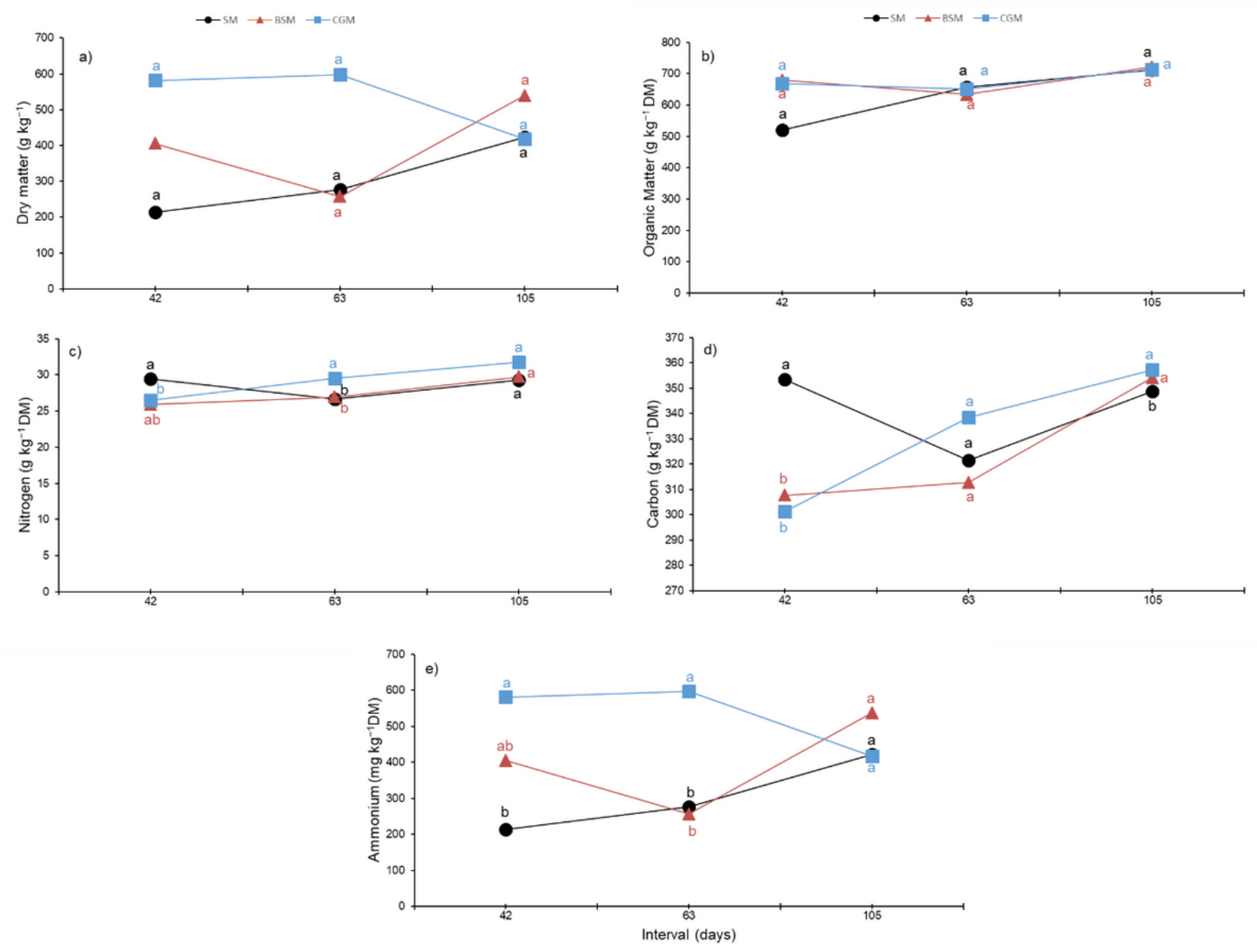

\section{Figure 3}

Dry matter, organic matter, $\mathrm{N}, \mathrm{C}$ and $\mathrm{NH} 4+$ content of the manure, deposited in the soil, of Nellore cattle fed with rumen undegradable protein source during the finishing phase in feedlot. SM = manure of animals fed soybean meal as a source of rumen degradable protein (RDP), BSM = manure of animals fed by-pass soybean meal as a source of rumen undegradable protein (RUP), CGM = manure of animals fed corn gluten meal as a source of RUP. Different letters represent significant differences by Tukey's Test ( $P$ $\leq 0.05)$ within the treatment vs time interaction. Chamber considered as an experimental unit $(n=9)$. The error bars representing standard error of the mean. 


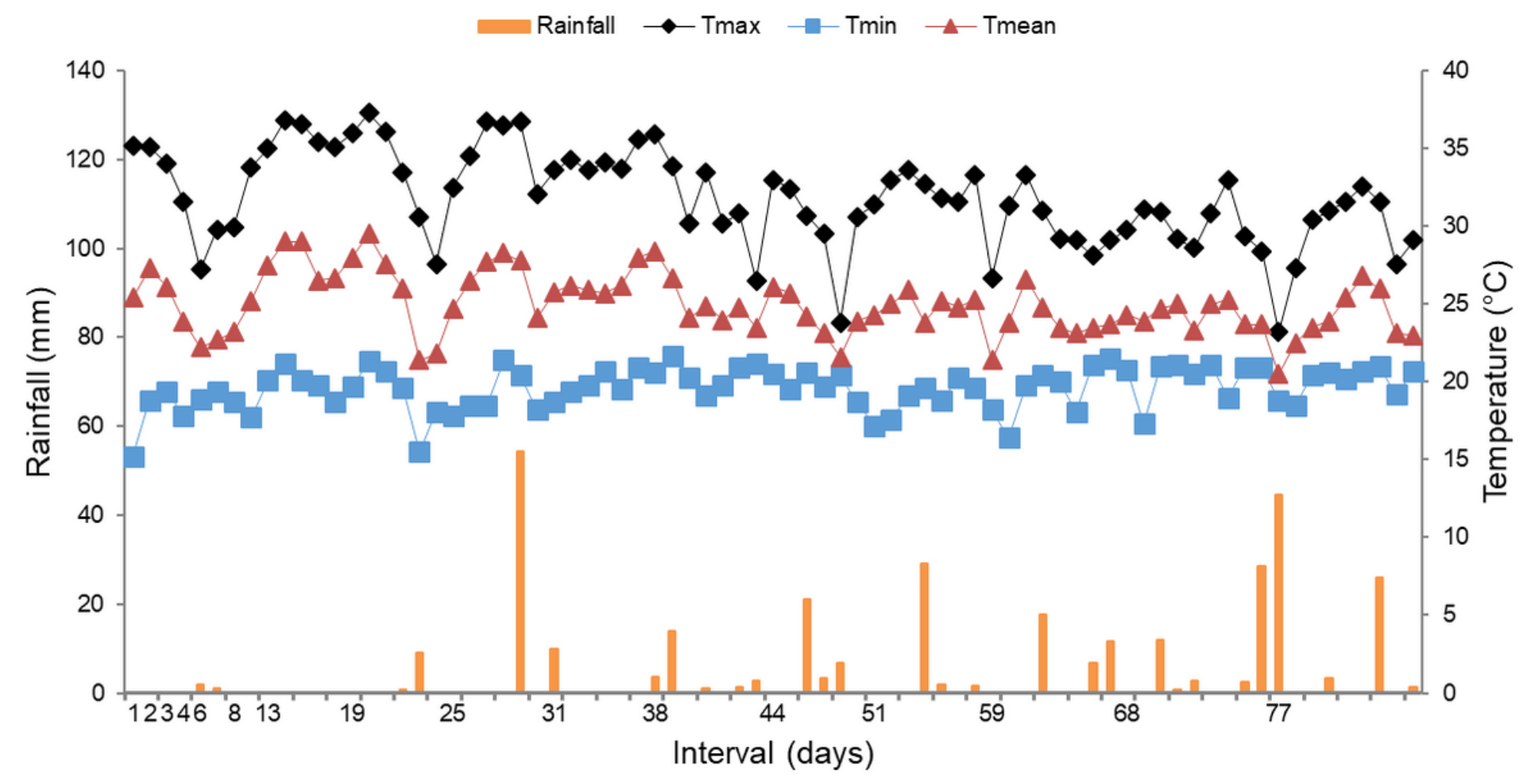

Figure 4

Daily rainfall and ambient temperature (daily minimum, mean, and maximum) throughout the $\mathrm{NH} 3$ emission sampling period. Data were retrieved from the Agroclimatological Station, Department of Exact Sciences, (FCAV/UNESP), located at $1 \mathrm{~km}$ from the experimental area. 

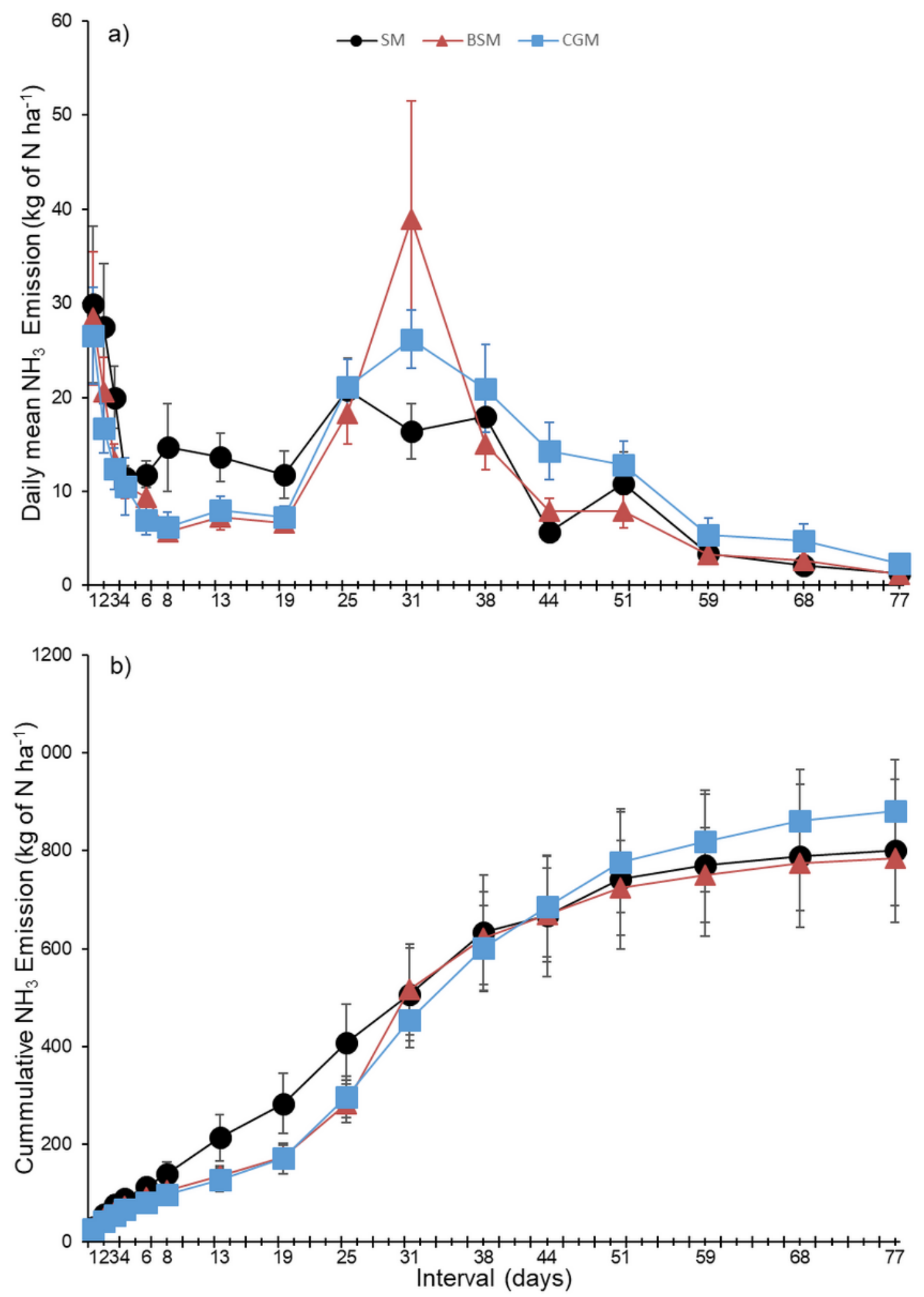

Figure 5

Daily mean (A) and cumulative (B) NH3 emission from the manure of Nellore cattle fed with sources of rumen undegradable protein during the finishing phase in feedlot. Evaluations started after the animals were removed from the feedlot. $S M=$ manure of animals fed soybean meal as a source of rumen degradable protein (RDP), BSM = manure of animals fed by-pass soybean meal as a source of rumen undegradable protein (RUP), CGM = manure of animals fed corn gluten meal as a source of RUP. 
Chamber considered as an experimental unit $(n=9)$. The error bars representing standard error of the mean. 